\title{
A survey on the relationship between ownership structure, debt policy and dividend policy in Tunisian stock exchange : Three stage least square simultaneous model approach
}

\author{
Fatma Ben Moussa ${ }^{1}$, Jameleddine Chichti ${ }^{2}$ \\ ${ }^{1}$ University of Tunis el manar, faculty of economic sciences and management of Tunis, Tunisia \\ ${ }^{2}$ Business school of Tunis (ESCT), Manouba university, B.P. 2010, Manouba, Tunisia \\ *Corresponding author E-mail: bmoussa_fatma@yahoo.ca
}

\begin{abstract}
This research tests the efficiency of the debt policy, dividend policy and ownership structure as mechanism of resolution of agency conflicts between shareholders and managers due to the problem of overinvestment, in the limitation of the problem of the free cash flow. By estimating three stage least square simultaneous model and on the basis of a sample of 35 non-financial Tunisian listed companies selected for the period 2000-2009, our results are in favor of the theory of free cash flows of Jensen (1986) that stipulates that the debt policy represents the principal governance mechanism that can limit the risk of free cash flow. However, our empirical results do not confirm our hypothesis implies that the solution to reduce the level of free cash flow in the Tunisian firms with low growth opportunities is the use of policy dividends. It therefore appears that in the case of our sample, managers must settle their debts to creditors. They should thus allocate free cash flow to profitable projects. Thus, the debt reduces agency costs of free cash flow and present as a control mechanism which substitute dividend policy. Also, it is found that managerial ownership lowers the level of agency costs of free cash flow. However, the ownership concentration increases the risk of the free cash flow. Finally, regarding the impact of ownership structure on the payout ratio, our results support the idea that more risk aversion of the majority shareholders and their intention to expropriate minority shareholders through the extraction private benefits are the cause of a low dividend.
\end{abstract}

Keywords: corporate governance, free cash flow, debt policy, dividend policy, ownership structure, three stages least square.

\section{Introduction}

The debate on the convergence-of-interest hypothesis relief of the agency theory (Fama and Miller 1972, Jensen and Mackling 1976) as well as of the signaling theory. The main concerned actors are managers, shareholders and creditors. The basic idea of agency theory is that every agent looks for the maximization of his self-interest, from where the apparition of conflicts (Ross, 1977). In these conditions the idea that the financial markets are perfected is rejected. Indeed, these will be determined by asymmetries of information and conflicts of interest.

Several works tempted to estimate agency costs and to test their effect on the cost of capital and also on the firm value. Moreover, an abundant literature is interested in the possible relations between the choice of the level of leverage and agency problem. Two main cases have been exposed. First, debt may reduce agency conflicts resulting from opportunistic behavior of managers. We essentially mention the overinvestment problem (Jensen, 1986). Secondly, the debt aggravates shareholder-creditor agency conflicts. The most studied examples are the asset substitution problem, the problem of transferring wealth from the firm's bondholders to the stockholders and the under investment problem (Smith and Warner (1979), Jensen and Meckling (1976) and Myers (1977)).

In this study we are going to define the role of debt, dividend policy and ownership structure like control's mechanism of the manager's behavior for the firms generating free cash flows.
The concept of free cash flow has been introduced by Jensen (1986), it is cash flow in excess of that required to fund all projects that have positive net present values. The problem is how to encourage managers to disgorge the cash rather than investing it at below the cost of capital or wasting it on organization inefficiencies. Therefore, the affectation of the free cash flow is to the core of the problematic of agency relations.

Indeed, the distribution of this abundant free cash flow appears not constraint by the engagement to use them in the profitable investments, nor by the one to contribute them to operating expenses or to the repayment of the debt. From where the temptation for managers to affect these free cash flow to nonprofit investments or to destine them to other finalities as the inefficient restructuring plans or the increase of the size of the firm in the only objective to increase their remuneration (Dorff, 2007). In the context of the agency theory, leverage is considered like an efficient solution to conflicts of interests that can appear between shareholders and managers, contrary to the thesis of Modigliani and Miller (1958), where the capital structure is associated solely to a model of cash - flows, his importance is related to the capacity of creditors to exercise the control.

Thus in case of debt issuing the manager is obliged to face remittances of annuities (Jensen and Meckling (1976), to stop the current operations of the firm and to opt for its liquidation (Harris and Raviv (1990)), to be more competitive (Grossman and Hart (1982)) and to limit his discretionary behavior on free cash 
flow (Jensen (1986), Stulz (1990) and Pindado and De La Torre (2005)).

Also, the development of the relative theory to the corporate governance came to specify other mechanism in order to control managers and to reduce these conflicts. Among these control mechanisms we distinguish the ownership structure. Indeed, the composition of the shareholding of a firm as well as its degree of dispersion influences its strategic and financial orientations. In this case, several authors (Leland and Pyle 1977, Hermalin and Weisbach, 1991,; Himmelberg and al., 1999) consider managerial ownership as evident solution to agency conflicts that permits to align interests of managers on those of shareholders. Also, the majority of studies related to the effect of ownership concentration confirm the hypothesis of their positive role in the corporate governance. Berle and Means (1932) affirm that a diffuse ownership structure decreases the relationship between the ownership and the control and minimize, therefore, the role of value maximization. To this effect, Jensen and Meckling (1976) affirm that agency costs decrease with the ownership since the ownership change lead to the alignment with interests of managers and shareholders.

Besides, theories on the corporate governance developed in parallel with the financial market development and the rise in power of the institutional investors and numerous reforms have been take place in many countries in order to reinforce the power of shareholders. The institutional investors play an important role in these transformations while requiring new norms favorable to shareholders andwhileexercising an important pressure on managers (Pound and Millar, 1999).

Moreover, in the case of agency conflicts, dividend policy has a dual role. On the one hand, it allows shareholders to effectively examine manager's behavior. Indeed, the dividend is seen as a mechanism for the resolution of agency conflicts. Thus, Jensen (1986) shows that the dividend policy is an effective means of control in the firm since it creates an additional control manager. Therefore the choice of an ideal dividend policy allows one hand to reduce agency conflicts and also to report to the market the intentions of the managers for decisions taken in firms they manage.

This research intends to test the efficiency of the ownership structure, dividend policy and the debt policy as mechanism of resolution of agency conflicts between shareholders and managers du to the problem of overinvestment, in the limitation of the problem of the free cash flow.

The rest of the paper is organized as follows. Section 2 reviews the previous theoretical and empirical research. Section 3 describes the empirical framework. The empirical results are presented in Section 4 and Section 5 concludes.

\section{Literature Review and hypotheses}

\subsection{Debt policy and agency costs of free cash flow}

The role of debt monitoring in reducing the agency costs of free cash flow is well emphasized in the theoretical and empirical literature.

Jensen [1986, page 323] defines the free cash flow, as the "cash flow in excess of that required to fun all projects that have positive NPV". He says that managers may use free cash flow to invest in negative NPV projects rather than return the free cash flow to the shareholders, for example as dividends. This problem is especially bad in firms who are mature and with low growth opportunities, as they have low profitable investments. However, by increasing debt with its required interest payments, managers are "bonding their promise to pay out future cash flows". Jensen indicates that firms with excess cash flows and low growth opportunities will use more debt financing for monitoring purposes. Stulz (1990) also suggested positive relation between leverage and free cash flow. But their theories find no support from empirical research of Chaplinsky and Niehaus (1990).

Also, Hart and Moore (1995) suggest that the debt doesn't resolve the overinvestment problem by the reduction of the free cash flow but rather it is its priority statute that limits the external amount can be collected by the firm.

Empirically, Lang and al. (1996) find a negative relationship between the leverage and the growth opportunities in firms with low growth opportunities in accordance with the free cash flow theory and find that changes in free cash flow lead to positive changes in leverage in the 142 American listed firms from 1970 to1989.

Gul and Jaggi (1999) develop a composite IOS measure by conducting a common factor analysis on six growth variables in order to classify firms with growth opportunities. The authors use data from 1989 to 1993 to non-regulated industrial firms. Results indicate that the debt has a positive effect on free cash flow firms with low growth opportunities in terms of the bottom quartile of IOS.

Vilasuso and Minkler (2001) develop a dynamic model that incorporates the issues of agency cost and asset specificity. Results based on an unbalanced panel of 28 publicly-held firms show that these two factors are significant determinants of the optimal capital structure of firms. Moreover, results show that agency costs increase with degree of assets specificity.

De Jong and van Dijk (2007) empirically examine the determinants of leverage and agency problems, and they test the relations between leverage and four agency problems i.e. direct wealth transfer, asset substitution, underinvestment and overinvestment. Based on a sample of Dutch firms from 1992 to 1997 , the results prove that the trade-off between tax advantages and bankruptcy costs determines leverage. Moreover, free cash flow and corporate-governance characteristics appear to be determinants of overinvestment. Despite findings that agency problems are present, there is no evidence for any relationship between agency problems and leverage.

$\mathrm{Li}$ and cui (2003) test the effect of capital structure on agency costs in 211 non-financial Chinese listed firms for the period from 1999 to 2001. Based on a system of simultaneous equations, results prove that firms with high debt to asset ratio have high ratio of annual sales to total assets and high ratio of returnon-equity. In this case, creditors are more concerned about the payment of interest and of principal and will have incentives to monitor the firm. Consequently, a capital structure with high debt decreases agency costs. Results also show a Positive relationship between ownership concentration and the return-onequity ratio. This is because the blockholders have a strong interest in firm performance and therefore a high capability to monitor manager in order to reduce agency costs.

$\mathrm{Wu}$ (2004), using 833 observations of listed Japanese firms for the period 1992-2000 tests the disciplinary role of ownership structure in corporate capital structure policy. Estimating OLS regression with leverage ratio as the dependent variable and several independents variables which are ownership structure, free cash flow, and growth opportunities, the results confirm that the leverage has a positive effect on free cash flow greater for firms with low growth opportunities than firms with high growth opportunities.

Zhang and Li (2008) employ multivariate tests and univariate tests to analyze the hypothesis which suggests that increase of leverage may reduce agency costs. Based on a sample of 323 UK companies, the results confirm that the increase of leverage does reduce agency costs. Nevertheless, when the leverage is sufficiently high, the effect additional increase in leverage has a positive and non-significant effect on agency costs. Finally, no significant evidence is found when testing whether the effect of leverage on agency costs becomes stronger when the differences of leverages of firms at different leveraged stages getting larger. Nekhili and al (2009) test the capacity of governance mechanisms, in the limitation of the problem of the free cash flow in 
case of French firms. By estimating three stage least square simultaneous model, results prove that distribution of dividends rather than debt level - that leads to reduction of free cash flow risk.

Recently, D'Mello and Miranda (2010) present a direct test of the overinvestment control hypothesis that states that long-term debt influences the degree to which firms overinvest. They do so by examining the pattern of overinvestment in cash and capital expenditure around new debt issues by unlevered firms. Based on a sample of 366 debt issues between the year 1968 and the year 2001 by firms that have been unlevered for at least three years, the results confirm that issuing debt leads to a reduction of overinvestment. Also, this relation is more significant for firms with poor investment opportunities confirming that debt plays an important role in reducing excess investments in firms that have the highest agency problems.

Agostinho and Prudencio (2010) analyze the capacity of the capital structure policy, the dividend policy, the board and the ownership structure and the practices of social responsibility in the limitation of the free cash flow risk. Using a sample of 298 firms of the NYSE Euronext of the year 2007, the results show that corporate governance mechanisms limit the arbitrariness of the management. In particular, the results confirm the role of leverage in reducing agency costs of free cash flow

Based on these theoretical and empirical works, the following hypotheses apply:

H1: Free cash flow level will be lower at higher levels of debt H2: Leverage is positively related to free cash flow in the firms with low growth opportunities and generating free cash flows.

\subsection{Dividend policy and agency costs of free cash flow.}

"The best test of good governance is to pay good dividends." Lim Hua Min, 2004, Chairman of Phillip Securities

The major agency conflict that affects the dividend policy is that between shareholders and managers due to overinvestment problem that managers can achieve at the expense of value creation for shareholders. Within the agency conflicts dividend policy has two roles. On the one hand, it allows shareholders to effectively monitor management. On the other hand, it allows managers to show that they ensure to maximize shareholder wealth and committing to their pay regular dividends. Indeed, these patterns limit the waste of company resources from the managers in project value destructive.

In addition, the distribution of dividends encourages managers, in some cases, to issue shares in the market. To do this, they must submit accounts, present a detailed explanation of past management and investments to undertake in the future that they had recourse to the self-financing.

In addition, sometimes the shareholders reject the subscription if they do not have a good appreciation of the managers. The comparison of these with the market is also a form of control. Also, the payment of dividends is a commitment on the part of managers to pay regularly to the shareholders a certain amount, and any reduction in this amount would be perceived as a sign of poor management.

Easterbrook (1984) presented two reasons why managers must distribute dividends:

1) The agency conflicts between shareholders and managers generate two types of costs: controlling costs borne by shareholders and risk aversion costs. Indeed, when the manager invests its human capital in the company, it becomes more risk averse. However, shareholders are concerned by the nondiversifiable risk because they can diversify their portfolios. In this case, the manager will choose less risky projects even if they are less profitable for shareholders. Manager may consider the risk in handling the debt ratio by using an appropriate dividend policy: if he finances investment projects by earnings, debt ratio reduce and the risk also. However, the financing of invest- ments by debt causes the transfer of wealth from shareholders to creditors.

2) Dividends push managers to use the market to finance investment projects. At the time of collection of funds, the market control the behavior of the manager who is is pushed, therefore, to promote the interests of shareholders. Control can be done by institutional shareholders, especially banks, financial intermediaries and buyers...etc. In addition, the issuance of new shares or bonds allows the company to adjust the level of debt and thus have a new interest rate so that neither the shareholders nor the creditors are disadvantaged. Managers, in this case, will be controlled by existing investors through their vote to the Board and the transfer of shares as well as the new shareholders who do not accept to acquire new shares unless they are compensated for potential agency costs in the form of lower prices. Thus, managers have an incentive to reduce agency costs.

Empirically, the authors concluded that the announcement of the dividend argued, therefore, the hypothesis of reducing agency costs of free cash flows.

Interested in the relationship between the distribution of dividends, free cash flow and investment policy, Damodaran (2006), says "we can observe the tendency of firms to distribute to their shareholders than their free cash flow to them would, considering the wealth paid to shareholders paid a percentage of free cash flow". In 1998, for example, the average wealth distributed according to the distribution ratio of free cash flow on all NYSE firms was $51.55 \%$. Thus, a percentage less than $100 \%$ indicates that the company distributes less than its cash flow and therefore increases liquidity. For these firms, the surplus liquidity appears in increased cash balances. However, a percentage greater than $100 \%$ is, however, that the company pays more wealth than its free-cash flow. These firms should fund these distributions of wealth is by tapping into their cash balance, either by raising new funds (issuing shares for example). Damodaran (2006) presented some arguments on the fact that firms pay less than what they have:

a) The managers of a company may have an interest in keeping the cash rather than distribute them. The desire to build an empire can make increasing the size of the firm an objective in itself. Or, management may feel the need to create a "cushion" to protect financial periods where profits become lower. In such periods, the "financial cushion" can reduce or mask falling profits and can thus enable managers to remain in place.

b) The firm may be uncertain about its future financing needs and may therefore decide to set aside cash to deal with unexpected or investment needs that were not anticipated.

c) The company may have volatile earnings and therefore conserve cash to allow smoothing dividends over time.

d) The bond firm may impose certain restrictions on the payment of wealth to shareholders, which may force the company not to distribute all available cash to its shareholders.

By focusing on firms experiencing overinvestment, Jensen (1986) predicts a positive association between the change in the level of dividends and the reaction of stock prices. Indeed, if the managers are trying to pursue the objective of maximizing shareholder wealth, the cash flows should be systematically distributed as dividend in case of positive NPV projects do not show up. If not, Jensen (1986) indicates that excess cash may be invested in projects where the expected rate of return is lower than the rate charged by the shareholders. This overinvestment is inevitably detrimental to the shareholder. Indeed, this situation has for objective to ensure that the interests of managers wanting to use excess resources in projects that support the increased size of the business growth of the company to increase their pay in parallel.

Jensen (1986) indicates that shareholders are urged to monitor the level of dividend when the company is in a situation of overinvestment. Therefore, an increase in the level of dividend will be favorably received if the company has no growth opportunities as it will have the ability to reduce the risk of overinvest- 
ment by minimizing the free cash flows. While a reduction dividend at companies with low growth opportunities is seen as bad news. Indeed, shareholders see that the dividend could be reduced the willingness of managers to increase free cash flow to invest in later projects aiming to serve their own interests.

Empirically, Lie (2000) showed a positive relationship between free cash flow and dividend increases. More specifically, the author stated that companies tended to distribute extraordinary dividends or making tender offers in the case where there are surplus funds non-recurring. However, in cases where companies have recurrent surplus funds, they will resort instead to an increase in ordinary dividends. Thus, when the risk of opportunism appears, shareholders require managers to pay dividends.

Bates (2005) shows that firms which do not distribute free cash flow will tend to invest in value-destroying acquisitions.

La Porta et al. (2000) argue two substitute agency models. Their first model posits that a better legal protection of the minority shareholders leads to more dividends being extracted from the firm. Their alternative model indicates that dividends are a substitute mechanism for legal protection.

Dividends are then paid out when firms try to establish a status for good treatment of shareholders and signal that expropriation does not have to be a concern. Hence, dividend policy acts as a corporate monitoring mechanism.

The research of DeAngelo, DeAngelo and Stulz (2004) use a sample of 25 industrial firms of NYSE, NASDAQ, and AMEX that distributed the largest total real dividends over the years 1950-2002.

Their empirical results demonstrate that dividend payments prevented significant agency problems. This reason suggests that firms with relatively high amounts of retained earnings are especially likely to pay dividends over time. In general, their proof supports the hypothesis that firms tend to pay dividends in order to alleviate agency costs associated with high cash and low debt capital structures that would finally result if they did not distribute dividends. DeAngelo et al. (2004) demonstrate that the dividend payments stop significant agency problems since the retention of the earnings give the managers' command over another access to better investment opportunities and without any monitoring.

Kato et al. (2002) support the hypothesis signaling and not the hypothesis of free cash flow based on a sample of 1362 dividend announcements made by Japanese firms during the period from January 1982 to April 1991. Thus, the dividend is used to minimize the free cash flows.

Borokhovich et al. (2005) confirmed the hypothesis which states that the distribution of dividends reduces agency conflicts, showing that, on average, firms whose board contains a high number of outside directors experience abnormal lower revenue around the announcement of the increase in the level of dividend distribution.

Recently, Pan (2007) studied the relationship between management entrenchment and dividend policy based on a sample composed of a large number of industrial enterprises in the United States during the period 1990-2003. The results of the study show that firms choose a combination of an effective system of governance and dividend policy that maximizes the firm value. In firms with low growth opportunities, there is maximization of shareholder value and thus the shareholders delegate more power to the managers to induce them to pay dividends rather than keep the money and extract private benefits. The study of Pan (2007) contributes to the growing literature on corporate governance and dividend policy studies like La Porta, Lopez - de Silanes, Shleifer and Vishny (2000), DeAngelo, DeAngelo and Stulz (2005), John and Knyazeva (2006)). These studies have shown that dividends mitigate agency problems. Pan (2007) confirms this argument. In particular, the results of the study corroborate $\mathrm{Hu}$ and Kumar (2004), which show a positive relationship between the likelihood of paying dividends and managerial ownership. Thus, the author shows a way to increase the firm value is to distribute dividends. Similarly, Harford, Mansi and Maxwell (2006) show that firms with low governance system have less liquidity. The authors explain this by the fact that these firms spend money more precipitously than firms with effective governance system.

Mahamuni and Balachandran (2010), show that the market reaction following the announcement of a special dividend in UK companies is positive. They also show that the price reaction is negatively related to growth opportunities and positively related to cash flows and firm size. In addition, the abnormal performance is positively related to future growth opportunities and the size of the special dividend for the year after the announcement. So, managers use dividends to signal future performance for firms with high growth opportunities and also to reduce agency costs in firms with low growth opportunities.

Finally, we can say that the distribution of a high level of dividend lead managers to turn to the market to finance investment projects. In this case, the market controls the behavior of the manager who is forced, therefore, to promote the interests of shareholders. This control can be done by institutional shareholders (banks). Moreover, as we have just stated that the issue of new shares or bonds allows the firm to adjust the level of debt and thus have a new interest rate, so, that neither shareholders nor creditors are not disadvantaged (Easterbrook, 1984). In this case, the control will be exercised by both existing investors through their vote to the Board as well as by new shareholders who are willing to acquire new shares unless they are compensated for any agency costs in the form of lower prices. Thus, managers have an incentive to reduce agency costs.

Our hypothesis concerning the relationship between the level of free cash flow and dividend are as follows:

H3: The risk of free cash flow will be reduced when the rate of dividend increases

\subsection{Ownership structure and agency costs of free cash flow}

The literature provides mixed guidance on the role of ownership structure as a corporate governance mechanism. The ownership concentration, the managerial ownership and the institutional ownership are three attributes that characterize the ownership structure of a firm.

Theoretically, for a firm whose capital is much dispersed, a minority shareholder won't have the incitement, nor the necessary funds to exercise a control on managers. While for a shareholder possessing an important part in the capital, he will grant more interest to the control of managers. This can be exercised by voting rights that he possesses, either by resources that he can use to supervise managerial actions, and either by the influence that he can exercise on the minority shareholders in order to sustain him in case of disagreement with managerial team.

Jensen and Meckling (1976) affirm that large shareholders are more motivated and have stronger power to guarantee shareholder value maximization, by aligning the interest of managers and shareholders and therefore reduce agency costs.

Zeckhauser and Pound (1990) test whether presence of large shareholders is related to systematic differences in expected earnings growth, dividend payout ratios and leverage ratios. Based on a sample of firms from 22 industries, results show that in 11 industries with a relatively open information structure, large shareholders are associated with significantly higher expected earnings growth rates.

More recent works suggest the benefits of large shareholders in a different context.

Pindado and De La Torre (2005) examine the effect of ownership structure on debt policy on the basis of a sample of 135 Spanish companies from 1990 to 1999. Results show that ownership concentration enhances debt financing in presence of free cash flow problem, even though debt is less used when there is problem of expropriation of minority shareholders by control- 
ling owners. Furthermore, they provide some results about the interaction between insider ownership and ownership concentration. Results show that ownership concentration does not change the relationship between managerial ownership and debt because when entrenched managers are in control, the monitoring role of outside owners become ineffective. Even though, the additional debt promoted by outside shareholders increase when managers are entrenched. So, the relationship between ownership concentration and debt is affected by managerial ownership.

Al-Deehani and Al-Saad (2007) test the impact of the ownership structure on the capital structure of the firms listed in the Kuwait Stock Exchange. Empirical results show a positive relationship between the amount of debt and the level of control rights relative to the level of cash flow rights. Moreover, findings point out a positive relationship between the level of debt and the existence of a manger from a controlling family. Finally, a third positive relationship between the amount of debt and the amount of controlling rights, and cash flow rights and a family concentrated ownership has also been found.

Driffield et al (2007) empirically examine the effects of ownership structure on capital structure and firm value among listed non-financial companies in Indonesia, Korea, Malaysia and Thailand. Results obtained from 3SLS model confirm that ownership concentration have significantly positive effects on leverage and firm value. Moreover, results show that ownership concentration tends to minimize agency costs for all groups of firms.

Syriopoulos et al. (2007) tend to show how different ownership structures may influence the allocation of firms' resources and investigate the impact of debt and dividend policies on corporate performance and firm market value. Based on a sample of 166 Greek companies listed in the Athens Stock Exchange, the empirical results confirm the importance of debt and dividends in terms of firm value creation by demonstrating a negative relationship between firm value and both leverage and dividend ratios in firms with high growth opportunities. Concerning the effect of ownership structure on firm resources, results show a positive relationship between ownership concentration and market value of firm, higher in the firms facing growth opportunities which are consistent with the idea that large shareholders have power to monitor management and reduce the free rider problem of corporate control associated with dispersed ownership.

Chen and Yur-Austin (2007) examine the efficiency of blockholders in mitigating agency costs such as managerial extravagance, poor asset management and underinvestment. Based on a sample of large publicly traded companies from 1996 to 2001, empirical results show that outside blockholders are more effective in mitigating managerial extravagance whereas inside blockholders are more vigilant about improving the efficiency of firm asset utilization. However, only managerial blockholders significantly overcome underinvestment problems, which may be attributable to their duality roles.

Nevertheless, Nekhili and al. (2009) show that the ownership concentration increases agency costs of the free cash flow in the case of the French firms, On the basis of a sample of Tunisian listed firms from 1995 to 2000, Omri (2003) show that the ownership concentration permits to reduce the managerial entrenchment and increase the possibility of the change in case of bad performance.

H4: Free cash flow level will be lower at higher levels of ownership concentration.

Managerial ownership has been extensively mentioned in the literature like a governance mechanism assuring the alignment of interests. Jensen and Meckling's convergence of interest' hypothesis suggest that managerial ownership serves to align the interests of mangers and outside shareholders. Indeed, managers take fewer decisions that will have some negative effects on the firm value because the part of costs that they will absorb, as shareholders, increases with their part of the capital. Therefore, managerial ownership property represents a mechanism that permits to reduce the cost of control supported by shareholders because it is supposed to reduce the managerial opportunism. However, according to the entrenchment theory, when the managerial ownership becomes very high, it becomes sometimes difficult to oust them even though their performance is judged dissatisfactory. Thus, they manage to dominate assemblies of shareholders and indirectly, all decisions taken by the firm (Daniel and Halperns, 1996), and try to reduce the possibility of takeover attempts (Stulz, 1988). The first developments of this theory are owed to Shleifer and Vishny (1989). The entrenchment process passes by the execution of specific investment that is going to facilitate the realization of projects in direct relation with their formation or experience, even though these are not necessarily most profitable for the firm.

Morck, Shleifer, and Vishny (1988) propose a model in which increased managerial ownership leads to entrenchment, where the manager will indulge in non-value-maximizing behavior. However, management's self-indulgence is expected to be less than if he has control but no claim on the firm's cash flows. The entrenchment hypothesis predicts that the value of the firm will decrease management ownership increases.

Poulain-Rehm (2005) tested the role of governance mechanisms in the limitation of the free cash flow problem in managerial and patrimonial listed firms. The author suggests that the effect of the ownership structure on the free cash flow affectation is not direct. The empiric results show that the impact of managerial and domestic ownership is negative and significant on the affectation of the free cash flow to the debt service for firms with low growth opportunities. This effect is rather positive in firms with high growth opportunities.

Using a survey sample of approximately 3800 Australian small and medium enterprises from 1996 to 1998 Fleming, Heaney and McCosker (2005) examine how agency costs change when ownership and control are separated. Empirical results provide a positive relationship between equity agency costs and the separation of ownership and control. Specifically, it is found that agency costs are lower in firms managed by equity holders, consistent with the argument that reducing the separation of ownership and control reduces agency costs. Finally, agency costs decrease as managerial and employee equity holdings increase.

Lee and Yeo (2007) examine the association between managerial entrenchment and capital structure of Asian firms. They find a negative association between managerial entrenchment and level of leverage in firms with higher agency costs of free cash flow. Specifically, the level of leverage decrease in firms with CEO who is president of the board, lower proportion of outside directors and higher CEO tenure. The authors also show a positive relationship between institutional ownership and level of leverage which indicates that active monitoring by institutional investors diminishes entrenched managers' incentives to avoid debt. Ghosh (2007) adopted the three stages least square simultaneous model approach to examine the interaction between leverage, ownership structure and firm value. Results show that capital structure, ownership structure and firm value are jointly determined. Specifically, the managerial ownership is a nonlinear determinant of firm leverage and also, leverage is a negative determinant of managerial ownership. These finding reveal the existence of a substitution monitoring effect between debt and managerial ownership. Then, the findings indicate that firm value decreases as promoters ownership increase. Since control of such companies can still be in the promoters' hands because of the dispersed nature of shareholding, such companies need to be subjected to more vigilant external monitors through debt and to the discipline of an active market for corporate control.

Florackis and Ozkan (2008) indicate that important governance mechanisms for the UK listed companies are managerial ownership, ownership concentration, executive compensation, shortterm debt and, bank debt. The authors examine the interactions between these mechanisms and firm growth opportunities in 
determining agency costs. The results show that impact exerted by governance mechanisms on agency costs vary with firms' growth opportunities. Specifically, high-growth firms face more serious agency problems than low-growth firms due to information asymmetries between managers, shareholders and debtholders. Moreover, results reveal that managerial ownership is more effective for high-growth firms.

McKnight and Weir (2009) examine the impact of ownership structure on three measures of agency costs which are the ratio of sales-to-total assets, the interaction of free cash flows and growth prospects and the number of acquisitions agency costs. To do so, employ a range of techniques to analyze the data collected for large UK listed companies: fixed-effects, instrumental variables, and Tobit regressions the authors. Results show that the changes in board structures have not affected agency costs. This suggests a range of mechanisms is consistent with firm value maximization. Results also indicate that having a nomination committee increases agency costs, which indicates that there are costs associated with certain governance mechanisms. Increasing board ownership also helps to reduce agency costs. Finally debt reduces agency costs.

In our study we presume, in accordance with the theory of interest convergence, that as the managerial ownership increases, their behavior comes closer of the one of shareholders. It results in a limitation of the free cash flow risk.

\section{H5: free cash flow level will be lower at higher levels of} managerial ownership.

The internationalization of financial markets made the institutional investors the major actors of the world economy given their large portfolio size. According to the OECD (2000), the institutional investors regroup four types of institutions: funds of pension, the mutual funds or investment Society, companies of insurances and the other institutional investor form as foundations or Private investment partnerships. Forester (1995) stipulates that the institutional investor presence pushes enterprises to be more conformable to recommendations of the various codes of good governance and can have an effect on the corporate performance by minimizing agency costs.

In this context, Bohn (2007) indicates that the movement of the governance benefitted from an important soaring in 2002 following the study achieved by the management consulting McKinseys \& Company concerning the institutional investors through the world, that showed that these investors would be ready to invest significant funds in the control of firms and to pay for a supplement until $40 \%$ to make a firm having good corporate governance practices.Several studies confirmed the positive role of the institutional investors in the corporate governance. Thus, McConnel and Servaes (1990) indicate that the implication of the institutional would result in their propensity to vote in general assembly (Brickley, Lease and Smith, 1988). Their study establishes that these investors exercise their voting rights more frequently than the individual shareholders and that they don't hesitate to oppose to managers decisions in order to defend their interests in case of dissatisfaction.

In their seminal paper, Pound (1988) presented three hypotheses concerning the effect of institutional ownership on firm performance: efficient monitoring, conflict of interest, and strategic alignment. According to the first hypothesis, institutional investors may have a positive impact on corporate performance if they monitored the managers effectively. They held more stocks and were more professional than private investors, so they had stronger motive to inspect the listed companies. Under the second hypothesis, institutional investors are less subject to information asymmetries than are other shareholders because they have greater resources, incentives for control firms and financial resources

Finally, the third hypothesis suggests that the institutional investors and managers find that cooperation is mutually advantageous. This cooperation reduces the beneficial effects on the firm value that could be result from the direction by the institutional investors.

According to Solh (2000), the institutional investors can influence the long-term investment decisions and encourage the company's management to choose the optimal projects from the point of view of shareholder interest.

Henry (2010) indicates that the institutional investors have a larger experience and they are more efficient monitors that the minority shareholders on the plane cost of control. Strategies that are accepted by the institutional investors are those that will be undertaken by firm through the accumulation of an important number of votes at the time of the board meeting what has the tendency to privilege the strategies creative of the value to the detriment of those destructive of the value to shareholders. Indeed, resources of which they arrange allow them to control the firm to a weaker cost that the other shareholders. It is due to the fact that they have a better access to information, because of their activity and the numerous investments that they achieve rich information on the environment and an excellent knowledge of the labor market. So institutional investors should help to facilitate the alignment of shareholder and managerial interests and, therefore, lower estimated agency costs. Darren (2010) identify the mechanisms that are effective in reducing agency costs using data for the period from 1992 to 2002 for listed companies on the Australian Stock Exchange. Empirical results indicate that institutional ownership has a negative effect on agency costs and there are non-linear relationships between managerial ownership and external ownership and the level of agency costs generated by companies. Though, the results provide limited evidence, in the effect of capital structure on agency costs. Finally, it is showed that internal governance and external shareholding influences are substitute mechanisms in their effect on the level of agency costs.

Several works test the interaction between corporate governance mechanisms. Agrawal and Knoeber (1996) examine the relationship between seven corporate governance mechanisms in mitigating agency problems between managers and shareholders. These mechanisms are: shareholdings of insiders, institutions, and large blockholders; use of outside directors, debt policy, the managerial labor market and the market for corporate control. Results show that ownership concentration and institutional ownership constitute a substitute to the external ownership. Moreover, the findings demonstrate a relation of complementarity between OPA, shareholdings of institutions, and large blockholders.

Kale, Ciceksever and Ryan (2006) estimate a system of three equations to analyze the interrelations among governance, debt, and activist institutional ownership as disciplining mechanisms. Using two-stage least squares, the findings of analysis indicate that mechanisms for disciplining managers serve as both substitutes (institutional ownership and debt) and complements (governance and institutional ownership).

Al Khouri (2006), find for a sample of listed firms on the stock market of Amman during the period 1998-2001, a positive and significant relationship between the institutional ownership and the firm value proxied by Tobin $\mathrm{Q}$ whether or not institutional investors are on the board of directors. This relationship is verified provided that the part of institutional ownership exceeds $25 \%$.

$\mathrm{Wu}$ (2004) shows that in the firms with low growth opportunities, institutional investors discourage managerial overspending by governance process and hence compensate for the debt monitoring. However, in the firms with high growth opportunities, institutional investors encourage higher leverage. Thus, Author finds that the institutional substitutes ownership the leverage in controlling the managerial self-interest.

McKnight and Weir (2009), prove that at higher levels of institutional ownership, institutions become less effective in supervising managerial actions and may not moderate the agency cost problem. 
H6: Free cash flow level will be lower at higher levels of institutional ownership.

\subsection{The relationship between ownership structure and dividend policy}

Several both theoretical and empirical work have attempted to scrutinize the relationship between the distribution of dividends and ownership structure.

The literature often makes the assumption that monitoring by shareholders replaces the cash distribution as a governance mechanism. However, some studies also explain a high participation of managers reduces the agency problems; eventually the amount to be distributed will be low. The nature of the relationship between dividend policy and ownership structure remains a very controversial point of view. It is useful to examine the relationship between ownership structure and dividend policy which is still a field of theoretical and empirical investigation.

According to Shleifer and Vishny (1986), ownership concentration creates the incentives for large shareholders to monitor the firm's management, which overcomes the free-rider problem associated with dispersed ownership whereby small shareholders have not enough incentives to incur monitoring costs for the benefit of other shareholders. Due to active monitoring from shareholders, managers are better aligned towards the objective of delivering shareholder value; resulting in greater firm performance. Indeed, firms with concentrated ownership have been documented to exhibit higher market values. The literature generally assumes that the control imposed by large shareholders replaces the policy dividend as a governance mechanism. Several studies confirm the negative relationship between the rate of dividend distribution and the level of control of the largest shareholder (Hu and Kumar, 2004; Maury and Pajuste, 2002) or the ownership concentration (Rozeff, 1982 and Lloyd et al., 1985; Dempsey and Laber, 1992; Moh'd et al., 1995).

By studying the relationship between ownership structure and distribution decisions of regular dividends and special dividends, Gadhoum (2000), supports that ownership concentrated in procreating stronger relationships between managers and shareholders reduces the asymmetry information and the need to report it to the firm through frequent changes of regular dividends. Based on a sample of 600 Canadian firms listed, the empirical results confirm the relationship of substitution between dividends and control by large shareholders. These results may also be evidence of expropriation of minority shareholders by controlling shareholders. According to Maury and Pajuste (2002) when there is a shareholder who holds more than half of the control of the firm, the level of distribution should be low. These authors also show that family control shareholder who is not director in the firm has a positive effect on the distribution, whereas if it is a director, it negatively affects the level of dividend payment.

Romon (1999) studied the determinants of dividend policy of listed French firms. By adopting an inductive qualitative approach , the author reports that the dividend policy of firm offering a low dividend yield and a high Marris Q be explained by the existence of a controlling family shareholders for which the tax on the dividend is not advantageous . Also, firms registering strong dividend yields have a dominant shareholder. However, the shareholder needs more liquidity and taxation does not seem to stop the distribution of a dividend. As for firms with less dividend yields, it differs from a non-uniform taxation of major shareholders and the lack of requirements imposed by the major shareholders. Willingness to serve a dividend with a yield equal to the market seems to be the most credible explanation.

The study of Korkeamaki, Liljeblom and Pasternack (2009) is particularly interesting. It involves estimating the effect of tax reform, which appeared in 2004 in Finland on the dividend policy of firms. The results generated are used to affirm the change in attitude of firms to meet new customer demands, specifically the majority shareholders.

For their part, Gugler and Yurtoglu (2003) show that the voting rights of the largest shareholder adversely affect the payout ratio which confirms the idea of expropriation of minority shareholders by the controlling shareholder in German firms. They show that the ownership structure violates the rule "one share - one vote» are being extensively reduce their dividend.

La Porta et al. (2000) indicate that in countries with better shareholder protection, like the US, firms pay more dividends. This finding is supported by the lower cash holdings of bettergoverned firms reported in Dittmar et al. (2003). Mitton (2005) documents that emerging market firms with higher corporate governance scores pay higher dividends. In addition, the dividend payout appears to be higher when investment opportunities are low.

Based on the work of La Porta et al. (2000), Faccio et al. (2001) indicate that the level of dividends distributed depends on the exposure of European and Asian firms to the risk of expropriation of minority shareholders following the separation of capital / votes of the dominant shareholder. This separation is important for affiliates to a pyramidal group where the extraction of private benefits is through intra-group transactions firms, which actually reduce the dividend payment. But in this conservative shareholders can predict the risk of expropriation in groups; the authors perceive that firms are less prone to reduce their dividend because of insurance a better reputation in the market.

Various studies conducted in Europe, especially by Ronneboog and Szilayi (2006) in Holland and Michaely and Roberts (2006) in the United Kingdom; support the idea that strong corporate governance makes a big dividend.

Jiraporn et al. (2008) show that dividend policy does not discipline management but rather strong governance encourages managers to pay high dividends. However, poor governance can also induce a generous dividend policy. Indeed, in some cases entrenched managers prefer satisfy its own interests may pay regular and growth dividends to shareholders. In this way, he somehow buys peace with its shareholders. They will then receive a certain level of liquidity is considered sufficient to be well informed. This substitution hypothesis was rejected by La Porta et al. (2000), but has been supported by many researchers like Nielsen (2006), Jiraporn and Ning (2006), Officer (2007) and Pan (2007).

Similarly, Albouy and Bonnet (2009) confirm that the dividend policy depends on the style of governance. Comparing two types of firms (Boeing and EADS), the authors indicate that Boeing is part of a shareholder logic encourages the distribution of dividends and this separately from its investment policy, while EADS, which is a partnership firm perceives dividends as a residual variable. At Boeing, the dividend should reassure shareholders about the future of the firm. At EADS dividend is a big problem and it is the subject of ongoing debate and intense conflict between public shareholders and employees.

For their part Renneboog and Trojanowski (2007) indicate that the presence of these large shareholders can monitor and discipline management and the controlling shareholder, but their impact on the distribution is ambiguous:

a) If the control exercised by these blocks is important to reduce agency costs, then it is not necessary to use dividend policy as a control mechanism. In this case, the relationship between these two governance mechanisms is a substitution relationship.

b) In case the shareholders cannot effectively control the managers, they will promote the distribution of dividends to minimize the level of free cash flow. In this case, there are two complementary mechanisms of governance.

c) Finally, the shareholder blocks may also cooperate with the majority shareholder to share with him the private benefits. They then have a negative impact on the distribution of dividends, without being referred to the substitution between governance mechanisms. 
Based on a sample of 985 authors show that in UK listed firms between 1992-1998, the presence of block holders, improves the distribution of dividends to reduce agency costs of free cash flow.

Recently, Kouki and Guizani (2009) found that Tunisian firms, whose ownership is highly concentrated, encourage the distribution of dividends. The authors highlight the significant impact of the level of free cash flow on dividend policy and affirm the complementary relationship between the presence of block holders and the distribution of dividends in the resolution of agency conflicts.

More recently, Harada and Nguyen (2011) examining the relationship between ownership concentration and dividend policy based on a sample of listed firms in China during the period 1995-2002. The empirical results show that ownership concentration negatively affects the dividend policy under the assumption that the expropriation of minority shareholders. This contradicts the argument that the dividend policy replaces inspection by shareholders and rather supports the idea that controlling shareholders expropriate private minority shareholders at the expense of profits. Also, the results show that firms distribute more dividends when debt levels are high to prevent the transfer of wealth to the creditors.

This whole both theoretical and empirical literature has led us to hypothesize that in cases of conflict of agency dividend payment is used to discipline the manager. Also, we can say that the majority shareholders provide financial resources to the company. In against part, they expect significant compensation either in the form of dividend or capital gains. So long as the participation of the majority shareholders in the capital increases, they will be more motivated to protect their investments and therefore the role of executive control strengthens. Also, the larger the share of the majority shareholders in capital increases, their voting power and influence increased, by providing a great ability to control the actions of managers. Thus, they can act on the strategic and operational decisions of the firm. In particular, they will prefer a higher dividend level in order to better control the managers. Therefore, our hypothesis about the impact of ownership concentration on the level of debt is as follows:

H7: There is a positive association between the ownership concentration and the dividend payout

Most studies on the impact of managerial ownership on dividend distribution support the negative effect (Jensen, 1986; Alli. et al, 1993; Mollah et al., 2000; Poulain-Rehm, 2005 and $\mathrm{Hu}$ and Kumar, 2004). This can be explained by several reasons: first, the assumption of entrenchment, the managers of the firm may limit the payment of dividends in the goal of increasing free cash flow to facilitate the expropriation. Second, the assumption of substitutability advanced by Jensen (1986), distribution of a high level of dividends can limit the discretionary funds of the firm. However, in the case of firms where managers are usually the main shareholders, it is reasonable to assume that they are less likely to carry unprofitable investments and destroy the value of the firm and therefore a high participation of managers solves some of the agency problems, therefore, the need for distribution of dividends is much reduced. So for these firms dividends are a residual and the amount of dividend to be paid will be low Alli et al, 1993. Poulain- Rehm , 2005). Finally, we can say that from the combination between the interests of managers and shareholders, results a lower payment that this combination may alleviate problems of free cash flow. Our hypothesis is therefore as follows:

H8: There is a negative association between the managerial ownership and the dividend payout

In the United States, Grinstein and Michaely (2003) report that institutional investors tend to depart from firms that do not distribute dividends. In addition, in the United States, Short et al. (2002) show a positive relationship between the shares held by institutional investors and dividend fraction.
Wu (2004) verifies the implications of the theory of free cash flow for the disciplinary role of the ownership structure in the dividend policy. The author claims this hypothesis by finding a positive correlation between free cash flow and dividends for Japanese firms with low growth opportunities. The results also show a positive impact of managerial ownership and the share of capital held by banks on the level of dividend primarily at those firms. This confirms the hypothesis that managerial ownership and institutional ownership minimize the need for dividend policy as a mechanism for reducing agency costs of free cash flow.

Based on agency theory, $\mathrm{Li}$ and Huang (2007) have tried to model the positive relationship between institutional ownership and the level of dividend.

Empirically, based on a sample of 364 manufacturing firms in China, for a period ranging from 2001 to 2003, Hang and $\mathrm{Li}$ (2007) show a positive relationship between institutional ownership and dividend payout.

Khan (2006) tested the relationship between ownership structure and dividend policy at 330 large firms listed in the United Kingdom. The empirical results show that firms adjust dividends to rise when the participation of insurance companies in the capital increase. Regarding the participation of institutional investors in the capital of the firm, it can act as an alternative control mechanism, and this will reduce the need to turn to capital markets as a mechanism of external governance (Zeckhauser and Bat, 1990). So, according to the agency theory, relationship between institutional ownership and the level of dividend should be positive.

We can conclude that the two theories of the preference of the tax and the agency theory suggest that the relationship between dividends and institutional ownership is positive. Thus our assumption about the relationship between dividend policy and institutional is as follows:

H9: There is a positive relationship between institutional ownership and the dividend payout

\subsection{Interaction between debt policy and dividend pol- icy}

Study The relationship between debt policy and dividend policy is very important. Both policies appear to be strongly related. Indeed, both decisions influence the agency relationship in two ways: in the context of agency relationship, debt and dividend are considered as two solutions to conflicts of interest. In a context of asymmetric information, the two decisions convey information to the market, reducing the problem of adverse selection. And independence between these two elements is rejected and the optimal combination of them must be established. Recently, the study of the relationship between debt policy and dividend policy as governance mechanisms to minimize agency costs has received considerable attention and the large number of empirical studies in the United States on the relationship between dividends and risk free cash flow or from dividends, debt and risk free cash flow shows interest in the subject. (Nivoix, 2004; Pindado, 2005, Harada and Nguyen, 2006; Avazian et al, 2006; Brockman and Unlu, 2009 and Aggarwal and Kyaw, 2011). Some authors show that these governance mechanisms are substitutable; others say they are complementary in reducing agency costs. Thus, the relationship between dividend policy and corporate debt policy is empirically ambiguous and remains a controversial point of view.

Calais and Masulis (1976) introduced the hypothesis which states that the dividend can be considered as a means of transferring wealth from creditors to shareholders, reducing the value of creditors' rights. The creditors protect their investment in a better way by imposing restrictions on the assets and the level of dividends. However, if the firm does not pay dividends, creditors receive the payment of interest on less risky assets than those obtained on their original contracts. On the other hand, shareholders seeking the maximum dividend in order to cover 
possible future transfer to the creditors. So companies using debt regularly and more important need less use dividend distributions to control the level of their available cash. So, all things being equal, firms with a high level of debt should rely less on dividend distributions.

Jensen (1986) examines the role of dividends, debt and financial restructuring as a mechanism to reduce the risk of free cash flow. More specifically, he distinguishes the possibility of substitution between the use of debt and the distribution of dividends. According to him, it is certain that the payment of dividends reduces the funds available to the managers. However, even if the manager is committed to the shareholders regularly increase dividends in the future, there is no guarantee it will be well. However, the increase in debt entitles bondholders to affirm the bankruptcy of the firm in the case of non-repayment of debt. In other words, the debt in the future creates a forced restraint on liquidity of the firm minimizes the funds available to the manager while requiring him to perform better. However, the amount of dividend payment almost never changes erratically, as the firm prefers to send a clear and consistent messages to its shareholders, both in what concerns the flow that the compensation it can pay its providers of capital. Nevertheless, it is reasonable that a firm in maturity pays a higher level of dividends; investors do not understand that it deprives them of a portion of its cash flow if positive NPV investment opportunities are presented. Limited recourse to external financing makes it possible to reduce the cost of resources, hence creating longterm value for a higher level of profitability of projects. In addition, the reduction of free cash flow in the event of debt is slightly less than the sum of interest and regulations, because of the tax savings, higher or lower depending on the rate of corporation tax. In addition, in the use of debt may be limited because of the risk of failure. Therefore, even if the ability to long -term rate dividend is generally little bullish, dividends are a way that is both flexible and efficient, reduce free cash flows.

Jensen (1986) indicates that the use of debt is insurance for shareholders about the payment of dividends in the future. Indeed, managers must settle their debts to creditors. They must, therefore, assign the free cash flow to profitable projects. Thus, debt reduces agency costs of free cash flow and has, therefore, as a control mechanism which substitute's dividend policy.

Avazian et al (2006) conducted a study on listed companies in the United States and showed empirically that the decision to smooth dividends is optimal for firms that use more debt on the public bond market where information is asymmetric but not for firms that use market private bank where the problem of information asymmetry does not arise. So, the authors show that the dividend decision is related to the asymmetry of information between the managers of the firm and the creditors. Financial creditors, including banks, usually play a key role in most countries of the world (compared to bondholders) and are sensitive to the risk of bankruptcy of the firm. If managers pay large dividends, the probability of repayment of capital reduces. This explains why in some countries, these creditors put pressure on the managers, either through the inclusion of restrictive clauses in bond contracts, by rationing the amount of credit fixed in the short term in the case of banks.

Brockman and Unlu (2009) reaffirm the importance of the pressure exerted by the creditors of the company. Their study of 52 countries shows that the probability to pay dividends is lower in countries where creditor protection is very strong. The same idea was defended by Benito and Young (2003), which show, on a basis of a business in the United Kingdom for the period 19741999, as high levels of debt increase the probability sample a decrease in the distribution ratio. This same result was also confirmed by Fama and French (2001) on U.S. data, and Gwilym, Seaton and Thomas (2004) for the case of the United Kingdom. Allen et al. (2010) show a negative relationship between the dividend policy and the use of the firm to bank financing. The authors present two reasons for this negative relationship: (1) banks play a very important role as the behavior of the leaders of corporate borrowers controllers. (2) Banks limit the distribution of dividends to shareholders in order to guarantee the repayment of principal and interest on the part of firms. In addition, the results show that the participation of institutional investors in the capital of the company is a complementary mechanism to the debt policy in determining the level of dividend.

Nekhili et al. (2009) conducted a research aimed to verify the ability of some governance mechanisms: debt policy, dividend policy, the board of directors and ownership structure as limited the problem of free cash flow. The results have revealed the effectiveness of the dividend, the Board of Directors and managerial ownership in reducing the risk of free cash flow. Nevertheless, the results show that the use of leverage does not significantly affect the risk of the free cash flow, but negatively affect the distribution of dividends.

Aggarwal and Kyaw (2011) study the interaction between dividend policy and debt policy in multinational firms. The authors construct a model with two simultaneous equations in which the long-term debt ratio and dividend payout ratio are the dependent variables. The empirical results of the estimation by the method of tree least squares show that multinationals firms have a lower level of debt and a payout of dividends more than domestic firms. The results imply that those who determine the policies of the firm are interested in international diversification to reduce the level of risk and investors are pushing managers to reduce the level of debt in order to distribute more dividends. The dividend level is negatively associated with free cash flow.

Complementary relationship between debt policy and dividend policy

Several empirical studies have shown a positive relationship between debt policy and dividend policy. For example, Carpentier (1998), based on a sample of French companies in growth during the period 1988-1996, showed that firms with a level of high dividend are more indebted.

Also, Bebczuk (2004), focusing on the dividend policy of 65 firms listed on the Argentine during the period 2003-2004 found that firms with more access to debt distribute more dividends. Thus, firms that take more risk without recourse to debt prefer to pay lower dividends.

In addition, Miguel Pindado and De La Torre (2005), show by their empirical study of 135 Spanish companies that in addition to a high level of debt, the distribution of high dividends is recommended to prevent the firm overinvestment. Indeed, since the overinvestment is characteristic of firms with a high level of liquidity that can be caused by such a high level of debt. So, increase in parallel the level of dividend to reduce liquidity in the hands of managers and thus prevent inefficient overinvestment decision. So, a new bond issue requires a significant dividend payment to limit managerial discretion on new funds and thus avoid over-investment in the firm. The authors have shown that the relationship between the mechanisms of control of agency costs is a complementary rather than substitutable relationship.

Recently, Syriopoulos, Tsatsaroni and Roumpis (2007) studied the impact of financial decisions (debt policy and dividend) on the performance and value of the firm. In this study, the dividend policy has two aspects: it has a positive impact (firms with low growth potential) and a negative impact (firms with profitable investment projects) on the value of the firm. This result is related to the disciplinary role of dividend policy in reducing managerial discretion. In all cases the dividend policy and debt are complementary mechanisms.

As indicated in the literature, debt reduces agency conflits between shareholders and managers (Jensen and Meckling, 1976 conflict Jensen, 1986; ..). Several authors such as Jensen et al. (1992) and Dutta et al., (2002) argue that debt is a control mechanism substitutable to dividend policy. In addition, the debt may negatively affect the level of dividends due to agency conflicts that may exist between shareholders and creditors, especially 
bondholders. Indeed, some authors indicate that the bondholders may impose restrictions on the distribution of dividends to ensure repayment of their debts Kalay (1982) and Smith and Warner (1979). On the empirical side, the majority of studies confirm the negative impact of debt on the payment of dividends. Indeed, when the firm borrows, it will be regular accruals under fear that creditors put the company in judicial settlement when the debt service is not honored what drives them to reduce their payout ( Fama and French , 2001; Benito and Young, 2003; Yurtoglu and Gugler, 2003; Gwilym , Seaton and Thomas , 2004; Aivazian et al , 2006. Brockman and Unlu , 2009).

In addition, several authors show that firms with a level of high dividend are more indebted Carpentier (1998). These authors confirm the theory of hierarchical financing where dividend is funded by the use of debt in the event of insufficient funds.

Our hypothesis about the relationship between debt policy and dividend policy is as follows:

H10: The dividend payout will be reduced when the level of debt increases.

H11: The level of debt is higher when the dividend payout increases.

\subsection{Interactions between debt policy, dividend policy and ownership structure: a review of the empirical literature}

Several empirical studies have adopted the use of a simultaneous equations system to examine possible interactions between debt policy, dividend policy and ownership structure.

Jensen, Solberg and Zorn (1992) tested the existence of a possible interaction between the ownership structure of the company and its financial decisions. The authors are based on a simultaneous equation system whose dependent variables are the long term debt ratio, the dividend payout ratio and the insider ownership. Holding a sample of 500 U.S. firms during 1982 to 1987 , the empirical results confirm the hypothesis of substitution. More specifically, the authors showed that the managerial ownership has a negative and significant impact on the debt and dividend level, and that these two financial policies are substitutable. So, the authors confirmed the interdependence of these three mechanisms to control agency costs.

Agrawal and Jayaraman (1994) studied the interaction between debt policy, dividend policy and the ownership structure as three control mechanisms may be substitutable in reducing agency costs of free cash flows. According to the authors, the debt could be an alternative to dividends to reduce the agency costs attached to the free cash flow. In this case, the least leveraged companies should pay more dividends, all else being equal. Also, the participation of managers in the capital of the firm is a solution proposed by Jensen (1976) to reduce agency costs and therefore it is an alternative to dividends. Therefore, a firm in which the manaers hold a significant share in the capital will pay lower dividends. In addition, a negative relationship could be envisaged between the debt and the insider onwnership, when in non- leveraged companies, there is no debt as a mechanism to reduce agency costs free cash flow. The authors selected two groups each formed of 71 firms. The first group of indebted companies and the second group are composed of non- leveraged companies. A multivariate regression model is estimated to explain the level of dividends by a dummy variable taking the debt value 1 if the firm 's debt and 0 if not, by the percentage of equity held by managers, the percentage of free cash flow and finally the growth opportunities. The empirical results show that the free cash flow variable and the level of growth opportunities have no significant impact on the level of dividends. Also, the managerial ownership and debt are two substitutable mechanisms limiting the agency costs of free cash flow in non- leveraged firms. However, the major limitation of this study is the lack of distinction between firms with low growth opportunities and those with high growth opportunities which is essential in confirming the theory of Jensen (1986).

A study by Poulain- Rehm (2005) testing the allocation of free cash flow of family listed firms in France. The allocation of free cash flow, or debt or dividends, is used simultaneously as independent and dependent variable. Dependent when it comes to check the impact of agency costs on the reinvestment of discretionary funds, taking into account the ownership structure. But also independent when it comes to whether, alternatively, allocation and assignment of debt to the distribution of dividends are negatively related, ie if there is a substitution effect between debt and dividend distribution, as indicated by the theory. By taking as a sample 209 French listed firms over a period of five years, from 1997 to 2001, the empirical results show that the allocation of free cash flow, or to repay debt or to pay dividends seems influenced by the ownership structure of firms. The results of the study confirm the implications of the theory suggesting that the control of the agency costs of free cash flow is lower in firms which, by nature, like the family firms with low costs agency. Indeed, there is a substitution effect between the control exercised by shareholders and other external disciplinary mechanisms. Also, this substitution effect is exerted, in some cases, in firms with high growth opportunities.

Similarly, Chen and Steiner (1999) studied the relationship between these three controls, but based on a system of four simultaneous equations in which the manager ownership, the rate of dividend payment, the medium and long term debt medium and risk are the dependent variables. Tests conducted on 685 U.S. companies in 1994, the authors have shown that managerial ownership and dividend policy are substitutes. Also, a relationship of substitutability between dividends and debt is recorded. Finally, this result is confirmed in the relationship between institutional ownership and managerial ownership.

Mahadwartha (2003) tested the impact of debt policy and dividend policy on managerial ownership in the manufacturing firms listed on the Jakarta Stock Exchange during the period ranging from 1993 to 2001 . The author used as the dependent variable managerial ownership in year $\mathrm{t}+1$ and the independent variables are the long term debt ratio, the rate of dividend yield, growth opportunities and the size of the firm . The empirical results show a negative relationship between managerial ownership, debt and dividends in accordance with the predictions of agency theory on the relationship of substitution between debt policies, dividend policy and ownership structure as mechanisms to control agency conflicts.

Kim et al. (2007) indicate that the debt policy, the ownership structure and dividend policy can be directly linked according to the asymmetric information theory and agency theory. To test the interrelationships between these three variables the authors have constructed a model to three simultaneous equations in which the dependent variables are the ratio of total debt, the rate of dividend distribution and managerial ownership. The authors have also introduced control variables in the three equations to determine the factors that explain each of these control mechanisms. The results show that the managerial ownership has a negative impact on the debt. However, the relationship between debt policy and dividend policy is positive according to the entrenchment theory. In addition, the debt is negatively affected by the level of cash flow and liquidity ratio which is consistent with the pecking order theory of Myers and Majluf's (1984). Also, the dividend policy is positively related to debt and managerial ownership which confirms again the entrenchment theory. So there are three complementary mechanisms in reducing agency costs.

Florackis and Ozkan (2009) showed how the entrenchment may affect the agency costs through a sample of 840 U.S. firms over a period from 1999 to 2003. They introduced their model variables: total liabilities, short-term debt and dividends as internal governance mechanism to test whether the capital structure and 
dividend policy have a significant impact on agency costs. Also, they introduced the variable ownership structure for the control of a potential change in agency costs due to the variation of the variable. Their results show that the coefficient of the entrenchment is negative and statistically significant while the coefficients of the variables: short-term debt, dividends and managerial ownership are positive and statistically significant. Their results support the suggestions of Short and Keasy 1998 , Franks et al , 2001, Lasfer 2002; Ozkan , 2004 and Florackis , 2005 which show that managerial ownership, short-term debt and dividends are mechanisms the most significant control to limit the opportunistic behavior of managers.

By applying a model with three equations, Crutchley and $\mathrm{A}$ (1999) tried to verify simultaneously the interactions between dividend, the insider ownership and institutional ownership as controls agency costs. Based on a sample of 849 companies listed on the New York Stock Exchange for the period ranging from 1993 to 1999 and belonging to the industrial sector and using the method of least squares cross-sectional, the authors showed that institutional ownership is negatively related to agency costs of equity. In addition, the increase in the share of capital held by institutional investors in the company leads to increased earnings and reducing agency costs. Also, the dividend may be a substitute for debt, it is positively related to institutional ownership, but it is not influenced by the insider ownership. Finally, the results show that institutional investors aim of profitable free cash flow to promote the payment of dividends.

Miguel Pindado and De La Torre (2005) have proposed a model of four simultaneous equations that explains the relationship between the different control mechanisms in agency costs (debt, dividends, internal ownership and ownership concentration). Also, the authors have incorporated the non-linearity of the internal property and the ownership concentration in their analysis because it can affect the relationship between the variables mentioned above. Based on a sample of 135 Spanish firms, the empirical results show that the relationship between the control mechanisms of agency costs is a complementary rather than substitutable relationship.

Huson (2009) adopts a logit model to examine the relationship between managerial ownership and agency conflicts approximated by the level of risk, debt and dividend policy . The study covers the period from 1997 to 2001 . The empirical results show a positive and significant relationship between low risk and managerial ownership and a negative relationship between high level of risk and the ownership. In addition, the debt policy that serves as a mechanism to control agency conflicts is positively related to the ownership concentration in the hands of managers. But the dividend policy as a mechanism to control agency conflicts has no significant impact on managerial ownership. Finally, institutional ownership that serves as an external means of control has a negative impact on the managerial ownership.

In addition, some studies try to explain the impact of the ownership structure, the debt and dividend policy on the firm value. Harjito (2006) studied the relationship of substitution between debt policy, managerial ownership and dividend policy as mechanisms to control agency in the context of Malaysia problems. The author suggests that if the substitution relationship between the control mechanisms of agency costs exists, the agency problem can be reduced through this relationship. Reduce the agency problem may therefore increase the value of the firm. In this study the author has constructed a four simultaneous equations in which the dependent variables are the level of debt, the rate of dividend distribution, managerial ownership and corporate value measured by the ratio Tobin Q. Holding a sample of 396 listed firms during the period from 2001 to 2004 and estimating the model by the method of double least squares, empirical results show that the substitution relationship between the three control mechanisms is cited not checked. This relationship only exists for the relationship between debt policy and dividend policy. In addition, debt positively affects the value of the company. Jen- sen (1986) indicates that this positive relationship is connected to the role of debt in the control of managerial behavior. Indeed, the use of debt pushes the manager to work more effectively to fulfill its commitments to creditors resulting in an increase in the value of the firm. Similarly, the dividend policy has a positive impact on the value of the firm. Indeed, the increase in dividend carries a positive signal to investors about the future situation of the company that pushes them to invest more in new projects. Also, the high amount of dividends is a signal to investors that agency costs are reduced.

Hassan (2009) examines the interaction between the ownership concentration, capital structure and the firm value. To do so, the author has selected a sample of 100 non-financial firms listed on the Australian Stock Exchange during the period 1993-2008. Based on a model with three simultaneous equations estimated by the 3 SLS method, the results show that corporate governance and corporate finance are intimately related.

\section{Methodology}

The review of the empirical literature treating the role of the debt policy, dividend policy and the ownership structure, as mechanism of resolution of agency conflicts between shareholders and managers due to the overinvestment problem brings us to note the contradiction and the empirical result ambiguousness don't seem again today to permit to succeed to the robust findings. It is therefore useful to spread knowledge on this topic and to see if the same factors keep in a different environment such the one of Tunisia.

\subsection{Sample Selection and definition of the variables}

\subsubsection{Sample selection}

Our sample consists of firms listed on the Tunisian stock exchange. Because banks and insurances are subject to specific rules and regulations, their leverage is severely affected by exogenous factors. So, Following Rajan and Zingales (1995), we exclude all firms categorized as "Financials" and focus exclusively on non-financial firms. Moreover, we eliminated firms not having long term debts (variable important of the model). Data used is provided by the Tunisian Stock Exchange and the Council of Capital Market through respectively their official bulletins and their annuals reports covering the period from 1999 to 2009 . The analysis is about the period from 2000 to 2009. The year 1999 serves to calculate some parameters that are variations. Our final sample consisted of 35 firms with a total of 206 firm year observations.

\subsubsection{Definition of the variables dependent variables}

We use three dependent variables in this study: the leverage (measured by the long term debt ratio), dividend payout ratio and the risk of free cash flow.

\section{Fee cash flow:}

The literature provides mixed guidance on the measures of free cash flow, which Jensen (1986) defines as cash flow left after firms have invested all available positive NPV projects. Since the value of positive NPV projects is unobservable, free cash flow is difficult to measure in practice. The most commonly used FCF definition is the one suggested by Lehn and Poulsen (1989). Their measure of FCF is the operating income before depreciation minus taxes, interest expenses, and preferred and common dividends. Also, some authors define it as the operational income before depreciation, capital expenditures and taxes, divided by the book value of total asset In order to eliminate any size effect (Lang and al., 1991). Gul and Tsui (1998) argue that these measures of FCF by themselves do not provide a measure of the availability of positive NPV projects. However, 
in combination with low growth, they suggest the existence of cash flow in excess of that required to fund positive NPV projects.

Recently, Richardson (2006) constructs a measure of free cash flow. This measure is "the cash flow from operations, plus research and development expenditure less the 'required' maintenance less the "expected' level of investment". Richardson applies "the label 'free' cash flows to the resulting measure, which is cash flow less the assumed non-discretionary and mandated components of investment". He suggests "The stated goal is to create a measure of the amount of cash flows that are not encumbered by the need to maintain the existing assets of the firm".

In our study we measure cash flow as:

Cash flow $=\frac{\mathrm{OI}-\mathrm{T}+\mathrm{D}-\mathrm{NI}-\Delta \mathrm{WCR}}{\mathrm{TA}}$

OI: operating income

T: tax

D: depreciation

NI: Net Investment

$\triangle$ WCR: change in working capital requirements

101 TA: total assets

To take account of growth opportunities we refer to studies of Miguel and Pindado (2001) Pindado and De la Torre (2009) and Nekhili et al. (2009), and we are going to measure the risk of free cash flow while multiplying free cash flow by the inverse of the Tobin Q. This last is measured like Dennis and al. (1994) which is market value of equity divided by book value of equity Also, in accordance with Nekhili et al., (2009), we consider the Tobin $\mathrm{Q}$ at the year $\mathrm{t}-1$. The authors argue that investments that are determined at the year $t$ concern growth opportunities relative at the year $\mathrm{t}-1$.

$$
\text { free cash flow risk } \mathrm{i}, \mathrm{t}=\frac{\mathrm{FCF} i, t}{\text { TobinQ } \mathrm{i}, \mathrm{t}-1}
$$

\section{Leverage:}

Surprisingly, there is no clear-cut definition of leverage in the academic literature. The specific choice depends on the objective of the analysis. On one hand, the total debt ratio has been used by several authors (Kremp and Stöss (2001) and Hovakimian 2005). Whereas Rajan and Zingales (1995) asserts that a ratio that includes the total debts doesn't constitute a good indicator, notably to put in exergue risks of bankruptcy of the firm. However, the short-term debt ratio has also been used by Titman and Wessels (1988). On another hand, some authors use the market value of debts as Taggart (1977), Titman and Wessels (1988), Flannery and Rangan (2006). Other authors as Benett and Donnelly (1993), Chang, Lee and Lee (2008), Huang and Song (2006) used both market value and book value of debt. In our study, we use the same definition of leverage as Lang et $\mathrm{al}(1996)$, namely the ratio of the book value of long-term debt to the book value of total assets in order to not neutralize the impact of agency costs joined to the leverage(Myers, 1977). This measure would not reflect recent changes in the markets. This measure has been used by Mello and Miranda (2010) who investigate the role of long-term debt in influencing over investments by analyzing the pattern of abnormal investments around a new debt offering by unleveraged firms. Pao (2008) precise that all studies that are interested in determinants of the capital structure judged that the difference between the market value of debt is very close to book value of debt.

$$
\text { Leverage }=\frac{\text { book value of long term debt }}{\text { book value of total assets }}
$$

\section{The payout ratio:}

The two variables commonly defined in the literature to measure the level of dividends is the dividend yield and the payout ratio. The rate of dividend distribution is measured by:

Payout ratio $=$ dividend per share $/$ Earnings per share

This is the measure most used in empirical research (Gugler, 2003; Reddy and Rath, 2005; Papadopoulos, 2007; AlMalkawi, 2007; Ahmed and Attiya, 2009, Al -Najjar, 2009). This classic ratio has the advantage of using two relatively stable elements annually (net income and dividend). In addition, it allows us to see if the company is " generous " or not, and to understand the tradeoff between the share of earnings retained within the firm (serving as a source of cash flow ) and the fraction of profit distributed to shareholders ( Easterbrook , 1984) since the retention rate is the complement to 100 payout

The limitation of this measure lies in the fact that there are companies that pay dividends even though their net income is negative. To this end, some researchers measure the payout ratio as the ratio between dividends and sales is where the benefit is negative; the payout ratio has no meaning. Although eliminating the years during which the company has a negative result can solve this problem but in this case the sample will be very small. Kim et al., 2007 using the ratio of distribution measured by the ratio between dividends and operating income when the net result is negative. In our case this problem does not arise since there instead of distributing dividends at the level of the beneficiary companies.

The rate of dividend yield is as follows:

Dividend yield =dividend per share/share price

This ratio indicates the requirement for shareholder returns relative to the value of their investment in the market. The advantage of this measure is that it is completely independent of any potential manipulation by insiders (Wu, 2004). This ratio has been used by several researchers (Ben Naceur et al (2006), Abe de Jong 2009).

However, this measure has some limitations. Indeed, depending on the share price, the yield is very sensitive to market fluctuations to reflect reliably the dividend policy of the firm, as also the problem of the choice of measurement courses (closing means ...). Also, this measure does not reflect the level of distribution of income of the company, including the relative importance of funds to shareholders and funds withheld.

\section{Independent variables:}

A detailed discussion of the variable construction is presented in Table 1.

The variables to be included in the equation for free cash flow:

Three explanatory variables are included as control variables on the basis of prior studies that investigate the determinants of free cash flow: state ownership, firm size and industry classification. According to the agency theory, state ownership is reputed to be inefficient due to the lack of capital market monitoring. Thus, it would incite their managers to pursue their own interests instead of those of their institutions. Managers of the private firms will have a stronger pressure of their environment and a more intense disciplinary effect from the capital market which can considerably reduce the inefficiency of these firms, (Lang and So, 2002). Indeed, through the control by goods and services market (competitive pressure of the sector), the badly managed companies should naturally disappear. However, often, public corporations are in position of monopoly and have not competitors. Besides, through the control by the financial market, badly managed firm's constituent targets for the more effective acquirers. However, stocks detained by the state are generally nontransferable and the state imposes a strict control on partners. Also, the diffusion of information concerning the firm to the capital market is often confused (political considerations, rules of public accounting). Also, managers who are members of the board of directors have no interest to contest the president decisions being discerned like emanating from the government. So we presume a 
negative relationship between state ownership and risk of free cash flow.

Firm size (proxy as logarithm of total assets) is used to explain the complexity of the surveillance required in the largest firms. We presume a negative relationship between the size and the risk of free cash flow in accordance with Jensen (1986), that precise that large firms, had much cash flow, would prefer debt financing in order to discipline managers what limits the risk of free cash flow. For the variable "industry" we anticipate that his sign is negative. Indeed, following restructurings of the Tunisian industrial firms, these will issue debts, what minimizes the level of free cash flow.

The variables to be included in the equation for the debt policy:

Harris and Raviv (1991) imply that the leverage of firms may be affected by many factors as investment opportunities, advertising expenditures, fixed assets, and the possibility of bankruptcy, profitability and uniqueness of product. For our empirical purposes, we focus on size, tangibility, tax, growth opportunities, profitability, and risk and industry classification.

\section{Firm size:}

Theoretically, the effect of size on leverage is ambiguous. On the one hand, some authors find a positive relationship between size and leverage, for example Rajan and Zingales (1995), Huang and Song (2002), Delcoure (2007) and Pao (2008). Larger firms are much more diversified than smaller one and so have lower variance of earnings, making them able to accept high debt ratios. On the other hand, some studies report a negative relationship, for example Kim and Sorensen, (1986), Titman and Wessels, (1988), Fluck et al. (2000) and Chen (2004). Due to asymmetry information, small firms are more likely to be underpriced by investors than large firms and could not get favorable price when financing through equity (Halov and Heider, 2005). While using debt with a fixed interest rate, small firms could suffer less loss from mispricing. Thus small firms should tend to consider using more debt, compared to large firms.

Tangibility:

Booth et al. (2001) state: "The more tangible the firm's assets, the greater its ability to issue secured debt." Consequently, a positive relationship between tangibility and leverage is presumed since tangible assets can be used as collateral. Also, in the case of conflict of interest between shareholders and creditors, Jensen and Mecklings (1976) demonstrated that the problem of overinvestment is less serious with more tangible assets. Several empirical studies confirm this suggestion (Rajan and Zingales (1995), Kremp et al., (1999), Hovakimian et al., (2001), Chen (2004), Drobetz and Fix (2005), Fattouh et al., (2005), Huang and Song (2006), Delcoure (2007), Pao (2008), De Jong et al., (2008)). On the other hand, Booth et al. (2001) suggest that the relationship between tangible fixed assets and debt financing is related to the maturity structure of the debt. In such a situation, the level of tangible fixed assets may facilitate to the firms to get more long-term debt, but the agency problems may become more severe with the further tangible fixed assets, because the information revealed about future earnings is less in these firms. In this case, a negative relationship between tangible fixed assets and debt ratio is presumed.

\section{Taxation:}

Numerous empirical studies have explored the impact of taxation on corporate financing decisions. According to the trade-off theory, a firm with a higher tax rate should issue more debt since it has more income to shield from taxes. However, for example Fama and French (1998) declare that debt has no net tax benefits. MacKie-Mason (1990) also stipulates: "Nearly everyone believes taxes must be important to financing decision, but little support has been found in empirical analysis."

Empirically, Graham and Tucker (2006) use a sample of 44 tax shelter cases to examine the degree of tax shelter activity and whether participating in a shelter is associated to debt policy. The results show that the firms use less debt when they engage in tax sheltering. The tax shelter firms appear under levered if shelters are ignored but do not appear under levered once shelters are considered.

Buettner et al. (2009), test the impact of taxes on the capital structure of German firms. The empirical analysis confirms that the local tax burden exerts important effects on an affiliate's leverage. This refers not only to external debt; the results show that a higher local tax has a positive impact on internal debt. This confirms that multinationals have access to other instrument which can be used to exploit the tax savings opportunities of debt finance.

\section{Growth opportunities:}

Jensen (1986) suggests that in case of low growth opportunities agency costs of free cash flow rise, so, debt should be issued. In doing so, probability of overinvestment by managers is reduced as firms commit to utilize future free cash flows for paying out investors. Consequently, a negative relationship between growth opportunities and debt ratios can be predicted.

Myers (1977) indicates that high leverage reduces the incentives of the managers and shareholders to invest in profitable investment opportunities, since the benefits return to the bondholders rather than to the shareholders. Thus, highly levered firm are less likely to exploit valuable growth opportunities as compared to firm with low levels of leverage. So the values of stocks diminish when there is information that the firm will issue stocks according to the asymmetric information theory. In this case, firms should not issue stocks and must use all internal resources and then financing via debt according to the pecking order theory.

Empirically, Aivazian et al (2005) examine the effect of leverage on investment on 1035 Canadian industrial firms for the period from 1982 to 1999 . They found a negative relationship between investment and leverage and that the relationship is more significant for low growth firms rather than high growth firms. Chen and Zhao (2006) find a non-monotonic and positive relationship between growth opportunities and leverage for more than $88 \%$ of COMPUSTAT firms. Billett et al. (2007) conclude that although growth opportunities negatively affect the leverage, there is a positive relationship between leverage and growth opportunities because of covenant protection. Debt covenants may attenuate the negative effect by attenuating the agency costs of debt for firms with high growth opportunities.

\section{Profitability:}

There are no consistent theoretical predictions on the effects of profitability on leverage. According to the trade-off theory, more profitable firms should have higher leverage because they have more income to shield from taxes. Also, according the free cash-flow theory would suggest that more profitable firms should use more debt in order to discipline managers. However, from the point of view of the pecking-order theory, firms prefer internal financing to external. Thus more profitable firms have a lower need for external financing and consequently should have lower leverage.

Most empirical studies observe a negative relationship between leverage and profitability, for example (Rajan and Zingales, 1995), (Huang and Song, 2002), (Booth et al., 2001), De Jong et al., (2008) and Karadeniz et al., (2009).

\section{Firm risk:}

Several authors stipulate that the level of leverage is a decreasing function of the gain variability. The negative relation is predicted by the Trade-off theory, the pecking order theory and the agency theory. Indeed, in a hierarchical financing perspective the volatility of profits can allow the firm to form a reserve of assets easily mobilizable in order to avoid an overinvestment problem. However, there are arguments demonstrating the effect positive of the risk on the leverage. Indeed, firms having a higher risk can also have a strategy of overinvestment that creditors have difficulty discerning because of the asymmetry of information between lenders and borrowers and will to reduce costs of agency. Huang and Song (2002) suggest based on find- 
ings of Hsia (1981): "As the variance of the value of the firm's assets increases, the systematic risk of equity decreases. So the business risk is expected to be positively related to leverage." Empirically, the effect of risk on leverage is ambiguous. On the one hand, some authors find an inverse relationship between risk and leverage, for example Bradley et al., 1984; Titman and Wessels, 1988; Friend and Lang, 1988; MacKie-Mason, 1990; Kale et al., 1991; Kim et al., 1998). Other studies suggest a positive relationship (Jordan et al., 1998; Michaelas et al., 1999; Wiwattanakantang, 1999; Kremp and Stöss, 2001; Esperança et al., 2003 and Pao, 2008).

\section{Industry Classification:}

Some empirical studies identify a statistically significant relationship between industry classification and leverage. Titman (1984) and Titman and Wessels (1988) show that firms manufacturing machines and equipment should be financed with relatively less debt, because they incur some very important liquidation costs. They use a dummy variable equal to one if the firm belongs to the industry sector and zero otherwise. Harris and Raviv (1991) declare, based on a survey of empirical studies: "Drugs, Instruments, Electronics, and Food have consistently low leverage while Paper, Textile Mill Products, Steel, Airlines, and Cement have consistently large leverage". More recently Awan and al., (2010) examine the relationship between growth opportunities and capital structure of the firms for sample of 110 manufacturing companies listed on Karachi Stock Exchange for 15 years (1982-1997) from 9 different sectors. They have found a significant positive relationship between growth opportunities and leverage that is greatly significant for sectors such as textile, sugar, cement, paper and jute. The possible explanation for such leverage behavior in these sectors could be that the owners of these firms, with a nominal foreigners' representation view the available growth opportunities as unsustainable and more risky, intend to pass on a higher risk to their creditors which would result in a high debt level. However, some empirical studies find no significant relationship between leverage and industry classification, we essentially mention the study of Drobetz and Fix (2005) for the Swiss firms and the one of Kim, Heshmati and Aoun (2006) for the non-financial listed firms in Korea. For the Tunisian firms, the industrial sector grants a big importance to restructurings requiring some enormous amounts.

The variables to be included in the equation for the dividend policy:

Under the assumption of perfect capital markets, Modigliani and Miller (1958) show that dividend policy is residual. However, if we accept the existence of imperfections such as bankruptcy costs or asymmetric information, the question is what are the factors that determine the dividend policy of the moment it has an impact on the value of the company?

\section{The level of free cash flow:}

According to the theory of free cash flow of Jensen (1986), when the firm has excess cash and low growth opportunities, the distribution of dividends is an option to reduce the substantial funds available to managers. All empirical studies we have just presented show the role of dividend policy as a mechanism for resolving agency shareholders / managers due to conflicts of overinvestment problem in the limiting problem free cash flow argue that the relationship between the level of free cash flow and dividends should be positive. In fact, firms that do not distribute free cash flow as dividends will tend to invest in valuedestructive acquisitions (Jensen, 1986; Lie, 2000; Kato et al, 2002; Bates, 2005; Pappadopoulos and Dimitrios, 2007; Pan, 2009). Thus, we expect firms secreting free cash flow and with low growth opportunities should pay more dividends.

The firm size:

Large firms are often assumed with stable funding and fewer problems of information asymmetry resulting in low financing costs. Also, larger firms can easily access the financial market (Crutchely and Hansen, 1989). In addition, they usually benefit from economies of scale in the payment of transaction costs, they may, therefore, be generous dividend.

Based on the pecking order theory, Fama and French (2002) and Wei and Zhang (2004) indicate that large U.S. firms pay high dividends due to the low volatility of their earnings. The authors show a positive relationship between the payout ratio and size. In a situation of free cash flow, we expect that the distribution of dividends is positively related to the firm size. Indeed, Jensen and Meckling (1976) show that agency costs increase with the size of the firm.

Fixed assets:

Studying the determinants of dividend policy, Mullah (2000) confirmed what Titman and Wessels (1988) and Alli et al. (1993) that firms with more tangible assets pay more dividends. In fact, most firms have fixed assets will be less problems between shareholders and creditors, which induces a high level of dividend. We therefore expect a positive relationship between the distribution of dividends and the tangibility of assets.

\section{The historical growth of activity:}

According to the Pecking order theory, firms pay lower dividends to shareholders if they have a strong historical growth. According to Myers and Majluf (1984), this growth leads to high investment costs and can act on the level of dividend for external financing is expensive. The implied relationship between dividend policy and investment policy is confirmed by Rozeff (1982). Recently, under the assumption of flexible dividend presented by DeAngelo and DeAngelo (2006), Blau and Fuller (2008), and Lee et al., (2011), firms reduce the dividend payout ratio when the growth rate increases. We expect a negative relationship between past growth of the firm and the level of dividend distribution.

\section{Profitability:}

According to the signaling theory, the most profitable firms pay more dividends. Indeed, the managers of profitable firms must submit to current and potential investors a signal about the financial health of the firm (Bhattacharya, 1979; Chang and Rhee, 2001; Ho, 2003; Aivazian et al, 2003).

Also, generally, increased performance leads to an increase in cash flow, and therefore a growing dividend (Jensen et al., 1992 and Fama and French, 2002). We assume, therefore, that the most profitable firms should pay more dividends.

\section{The level of risk:}

$\mathrm{Al}$-Najjar (2009) indicates that the risk is one of the most important determinants of dividend policy. Roseff (1982) states that a high level of financial and operating leverage led the firm to pay lower dividends, to reduce the cost of external funds. Thus, according to Chang and Rhee (2001), a firm with a stable and regular income can predict future income with greater accuracy. So, such a firm can commit to deliver a greater proportion of its earnings as dividends with a minimum of risk to lower its dividend in the future. This negative relationship is also supported by the agency dividend policy theory. We expect, therefore, a negative relationship between the risk and the payout ratio.

\section{The state ownership:}

The impact of state ownership on payout ratio is not clear. Based on a sample of 2134 Australian firms, Gugler (2003) shows that the variable on the state ownership negatively affects the distribution of dividends. The author shows that the agency problem is more severe in these firms. Asymmetric information allows managers to alternately smooth dividends and make them reluctant to reduce the level of dividends. However, it depends on the strategic objectives adopted by the government. In the case of emerging economies, Al- Malkawi (2007) indicates that the state ownership positively affect the rate of distribution. AlKuwari (2010) indicates that when the legal protection of investors is low, the state plays an important role in exerting pressure on firms to distribute dividends. This result also corroborates those of Glen et al. (1995), Al- Malkawi (2008) and Gugler's (2003). Similarly, comparing dividend policy of public and pri- 
vate firms, Michaely and Roberts (2012) show that private firm's smooth dividends significantly less than their public counterparts and that they pay relatively higher dividends than private firms.

Thus, like Glen et al. (1995), Gugler's (2003), Al- Malkawi (2008) and Michaely and Roberts (2012), we expect that the state ownership has a positive impact on the payout ratio.

To estimate our models we must examinate if there is presence of a multicollinearity problem.
Multicollinearity refers to a situation in which two or more explanatory/independent variables in multiple regression models are highly correlated. It can be detected through analyzing the Pearson correlation matrix. If the Pearson correlation coefficient exceed 0, 7 (limit fixed by Kervin, 1992), we conclude the presence of multicollinearity

Table 1: Definition and measurement of the variables

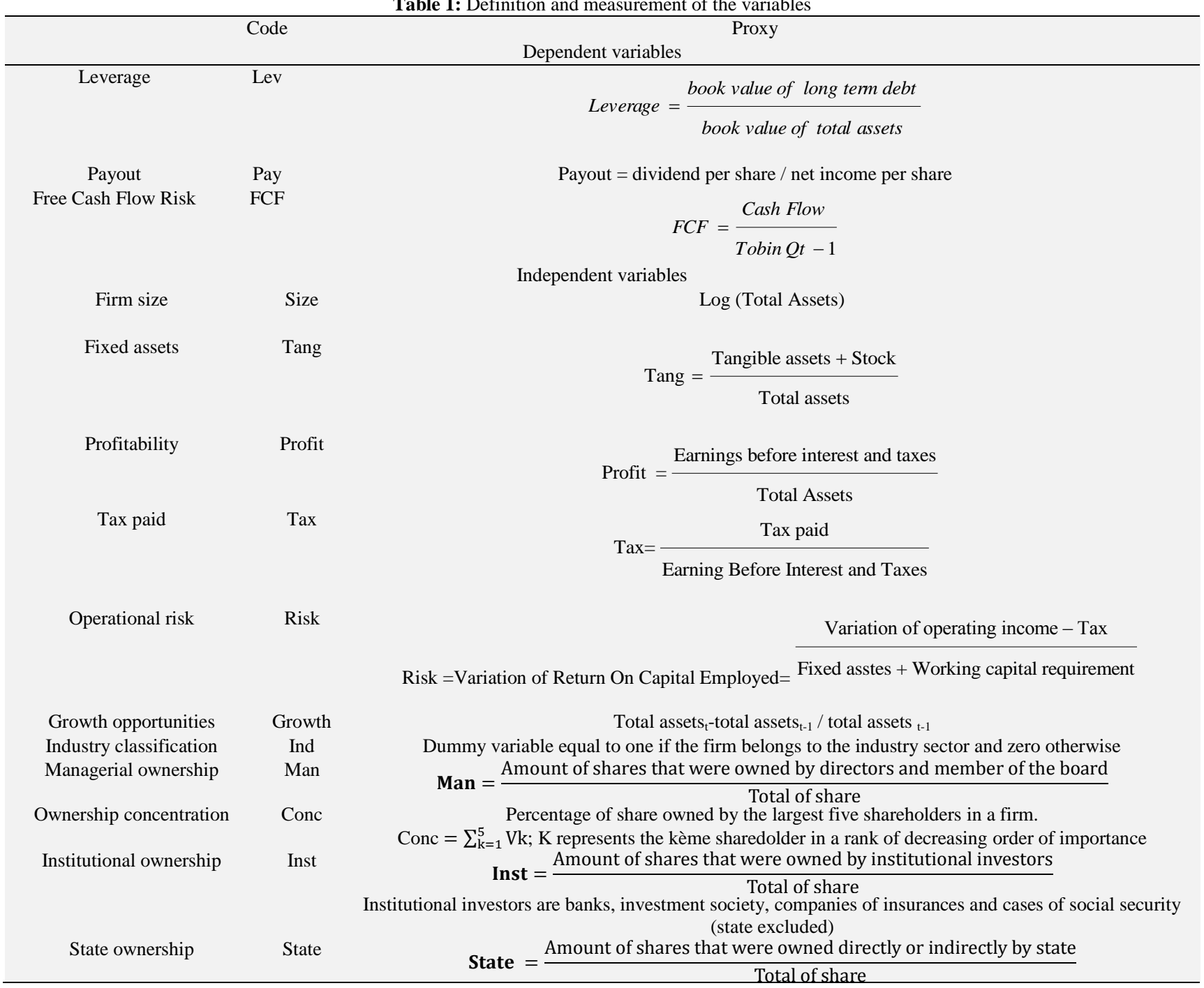

Table 2: The correlation matrix of the independent variables

\begin{tabular}{|c|c|c|c|c|c|c|c|c|c|c|c|c|c|}
\hline & Leverage & FCF & Payout & Size & Tang & Tax & Growth & Profit & Risk & Conc & Man & Inst & State \\
\hline Leverage & 1 & & & & & & & & & & & & \\
\hline FCF & $-0,067$ & 1 & & & & & & & & & & & \\
\hline Payout & -0.319 & 0.220 & 1 & & & & & & & & & & \\
\hline Size & 0,156 & 0,178 & $-0,310$ & 1 & & & & & & & & & \\
\hline Tang & $-0,043$ & $-0,124$ & $-0,187$ & $-0,061$ & 1 & & & & & & & & \\
\hline Tax & $-0,282$ & 0,107 & 0,439 & $-0,207$ & $-0,139$ & 1 & & & & & & & \\
\hline Growth & $-0,185$ & $-0,036$ & 0,181 & $-0,005$ & $-0,008$ & 0,092 & 1 & & & & & & \\
\hline Profit & $-0,511$ & 0,120 & 0,462 & $-0,121$ & $-0,196$ & 0,500 & 0,175 & 1 & & & & & \\
\hline Risk & 0,005 & $-0,079$ & 0,090 & $-0,037$ & $-0,057$ & 0,067 & $-0,093$ & 0,160 & 1 & & & & \\
\hline Conc & 0,316 & 0,232 & $-0,225$ & 0,244 & $-0,098$ & $-0,086$ & $-0,091$ & $-0,184$ & $-0,004$ & 1 & & & \\
\hline Man & $-0,110$ & $-0,156$ & 0,021 & $-0,238$ & $-0,079$ & $-0,204$ & 0,056 & 0,090 & $-0,003$ & 0,032 & 1 & & \\
\hline Inst & 0,404 & $-0,094$ & $-0,245$ & 0,050 & 0,186 & $-0,095$ & $-0,035$ & $-0,307$ & 0,089 & 0,104 & $-0,316$ & 1 & \\
\hline State & 0,3387 & $-0,042$ & $-0,295$ & 0,315 & 0,205 & 0,109 & $-0,127$ & $-0,37$ & $-0,005$ & 0,261 & $-0,642$ & 0,401 & 1 \\
\hline
\end{tabular}

Results in table (2) indicate that all Pearson correlation coefficients are less than 0,7 . Thus, we conclude the absence of a

Table (2) present the correlation coefficient associated to indemulticollinearity problem. pendent variables used in our models. 


\subsection{Specification of the simultaneous equations model and method of estimation}

\subsubsection{Specification and identification of the model}

A simultaneous equations approach particularly 3SLS is deemed to be appropriate on the basis of the interrelationships among the agency-cost-reducing mechanisms. This study uses a threeequation model with free cash flow, payout and leverage as the dependent

$\mathrm{FCF}_{\mathrm{i}, \mathrm{t}}=\alpha_{0}+\alpha_{1}$ Leverage $_{\mathrm{i}, \mathrm{t}}+\alpha_{2}$ Payout $_{\mathrm{i}, \mathrm{t}}+\alpha_{3}$ Conc $_{\mathrm{i}, \mathrm{t}}+\alpha_{4} \mathrm{Man}_{\mathrm{i}, \mathrm{t}}$ $+\alpha_{5}$ Inst $_{\mathrm{i}, \mathrm{t}}+\alpha_{6}$ State $_{\mathrm{i}, \mathrm{t}}+\alpha_{7}$ Size $_{\mathrm{i}, \mathrm{t}}+\varepsilon_{1 \mathrm{i}, \mathrm{t}}$

Leverage $_{i, \mathrm{t}}=\beta_{0}+\beta_{1} \mathrm{FCF}_{\mathrm{i}, \mathrm{t}}+\beta_{2}$ Payout $_{\mathrm{i}, \mathrm{t}}+\beta_{3}$ Man $_{\mathrm{i}, \mathrm{t}}+\beta_{4}$ Conc $_{\mathrm{i}, \mathrm{t}}+$ $\beta 5$ Inst $_{\mathrm{i}, \mathrm{t}}+\beta_{6}$ State $_{\mathrm{i}, \mathrm{t}}+\beta_{7}$ Size $_{\mathrm{i}, \mathrm{t}}+\beta_{8}$ Tang $_{\mathrm{i}, \mathrm{t}}+\beta_{9}$ Tax $_{\mathrm{i}, \mathrm{t}}+\beta_{10}$ profit $_{\mathrm{i}, \mathrm{t}}+$ $\beta_{11}$ Riski, $t+\beta_{12}$ Growthi, $t+\beta_{13} \operatorname{Ind}_{\mathrm{i}, \mathrm{t}}+\varepsilon_{2 \mathrm{i}}$

Payouti, $=\delta_{0}+\delta_{1} \mathrm{FCF}_{\mathrm{i}, \mathrm{t}}+\delta_{2}$ Leverage $_{\mathrm{i}, \mathrm{t}}+\delta_{3}$ Conc $_{\mathrm{i}, \mathrm{t}}+\delta_{4} \mathrm{Man}_{\mathrm{i}, \mathrm{t}}+$ $\delta_{5}$ Inst $_{\mathrm{i}, \mathrm{t}}+\delta_{6}$ State $_{\mathrm{i}, \mathrm{t}}+\delta_{7}$ Size $_{\mathrm{i}, \mathrm{t}}+\delta_{8}$ Tang $_{\mathrm{i}, \mathrm{t}}+\delta_{9}$ Growth $_{\mathrm{i}, \mathrm{t}}+$

$\delta_{10}$ Profit $_{\mathrm{i}, \mathrm{t}}+\delta_{11}$ Risk $_{\mathrm{i}, \mathrm{t}}+\varepsilon_{3 \mathrm{i}}$

$\varepsilon_{1 \mathrm{it}}=\mathrm{a}_{1 \mathrm{i}}+\mu_{1 \mathrm{it}} ; \varepsilon_{2 \mathrm{it}}=\mathrm{a}_{2 \mathrm{i}}+\mu_{2 \mathrm{it}} ; \varepsilon_{3 \mathrm{it}}=\mathrm{a}_{3 \mathrm{i}}+\mu_{3 \mathrm{it}}$

$\mathrm{i}=1 \ldots \mathrm{N}$ and $\mathrm{t}=1 \ldots \mathrm{T}$

$\mathrm{N}$ : the number of firms and $\mathrm{T}$ : the estimation period

$\varepsilon_{1 \mathrm{it}}, \varepsilon_{2 \mathrm{it}}$ and $\varepsilon_{3 \mathrm{it}}$, Error Term corresponding respectively to the first, to the second and the third equation,

$\alpha_{1} \ldots \ldots \alpha_{6}$ : representative parameters of the relative weight of each exogenous variable on the variable to explain «Free Cash Flow»; $\beta_{1} \ldots \ldots \beta_{8}$ : representative parameters of the relative weight of each exogenous variable on the variable to explain «leverage ».

$\delta_{1} \ldots \ldots \ldots \delta 11$ : representative parameters of the relative weight of each exogenous variable on the variable to explain "payout » $\alpha_{0}, \beta_{0}$, and $\delta_{0 \text { : }}$ constants corresponding respectively to the first, to the second equation and to the third equation.

\subsubsection{The identification condition in the model.}

Order conditions are determined equation by equation. They are verified when the number of endogenous variables excluded $\left(\mathrm{k}-\mathrm{k}^{\prime}\right)$ plus the number of exogenous variables excluded $\left(g-g^{\prime}\right)$ is superior or equal to the number of equations less $1:\left(k-k^{\prime}\right)+\left(g-g^{\prime}\right) \geq$ (e - 1).

The equation is under - identified if $\left(\mathrm{k}-\mathrm{k}^{\prime}\right)<\left(\mathrm{g}^{\prime}-1\right)$

The equation is exactly identified if $\left(\mathrm{k}-\mathrm{k}^{\prime}\right)=\left(\mathrm{g}^{\prime}-1\right)$

The equation is over - identified if $\left(\mathrm{k}-\mathrm{k}^{\prime}\right)>\left(\mathrm{g}^{\prime}-1\right)$

With:

G: number of endogenous variables of the model;

$\mathrm{K}$ : number of exogenous variables of the model;

$G^{\prime}$ : number of endogenous variables introduced in an equation;

$\mathrm{K}$ : number of exogenous variables introduced in an equation;

Rank conditions assure here that the model, under its reduced form, possesses a unique solution. The rank conditions for empirical identification are relatively complicated.

Table 3: The identification condition in the mode

\begin{tabular}{|c|c|c|c|c|c|c|c|}
\hline Equation & $\mathrm{g}$ & $\mathrm{K}$ & g' & $\mathrm{k}^{\prime}$ & $\begin{array}{l}\text { k- } \\
\text { k' }\end{array}$ & $g^{\prime}-1$ & Identification \\
\hline Equation 1 & 3 & 17 & 2 & 5 & 12 & 1 & $\begin{array}{l}\mathrm{k}-\mathrm{k}^{\prime}=\mathrm{g}^{\prime}-1 \text {; the } \\
\text { equation I is over } \\
\text { identified }\end{array}$ \\
\hline Equation 2 & 3 & 17 & 2 & 11 & 6 & 1 & $\begin{array}{l}\mathrm{k}-\mathrm{k}^{\prime}>\mathrm{g}^{\prime}-1 \text {; the } \\
\text { equation II is } \\
\text { over identified }\end{array}$ \\
\hline Equation 3 & 3 & 18 & 2 & 17 & 1 & 1 & $\begin{array}{l}\mathrm{k}-\mathrm{k}^{\prime}=\mathrm{g}^{\prime}-1 \text {; the } \\
\text { equation III is } \\
\text { just identified }\end{array}$ \\
\hline
\end{tabular}

\subsubsection{Method of estimation}

The model describes below is a simultaneous equations model of the leverage, payout and the level of free cash flow. We can estimate parameters of the system when equations are exactly- identified or over - identified. We distinguish limited information method and full information method. The first consist in estimating equation by equation the model by the two stage least square method. The second consider the model in its totality and we use here the three stage least square method (Cadoret et al. (2004)). Our model will be estimated by the three stage least square method with 206 observations on the period 2000-2009. The system of three simultaneous equations, for every firm $\mathrm{i}$ and every year $\mathrm{t}$, can be written:

$y=Z \delta+\varepsilon$

As, $y=\left[\begin{array}{l}y_{1} \\ y_{2} \\ y_{3}\end{array}\right]=\left[\begin{array}{ccc}z_{1} & 0 & 0 \\ 0 & Z_{2} & 0 \\ 0 & 0 & Z_{3}\end{array}\right]\left[\begin{array}{l}\delta_{1} \\ \delta_{2} \\ \delta_{3}\end{array}\right]+\left[\begin{array}{l}\varepsilon_{1} \\ \varepsilon_{2} \\ \varepsilon_{3}\end{array}\right]$

As, $y^{\prime}=\left(y_{1}, y_{2}, y_{3}\right)$ is vector of endogenous variables (free cash

flow, long term debt and payout),Vectors of the explanatory endogenous and exogenous variables of the equation of free cash flow $\mathrm{Z} 1$, leverage $\mathrm{Z} 2$ and payout $\mathrm{Z} 3$ are :

$Z_{1}=[$ Leverage, Man, Conc, Inst, State, Size,$]$

$Z_{2}=[F C F$, Size, tang,Tax, Growt, Profit, Risk, Ind $]$

$\mathrm{Z3}=[\mathrm{FCF}$, Leverage, Conc, Man, Inst, State, Size,Tang, Growth,Profit, Risk]

$\delta_{S}$ Represent the vector of coefficients of all explanatory variables (endogenous and exogenous).

For error term :

$E(\varepsilon)=0$

$E\left(\varepsilon \varepsilon^{\prime}\right)=\left[\sigma_{s h} I\right]$

In the case of the simultaneous equations, the interdependence of endogenous variables deal place to an interdependence of error terms, what calls at the time of the estimation on the three least square method. This method consists in estimating the system in three stages. The first two stages are those of the two least square method applied separately to every equation of the system under its reduced form. Therefore, in our case we have three equations to estimate. The reduced form of the system is gotten by the application of the following stages: while using vectors (4), we can define a matrix $B$ of three endogenous variable coefficients and a matrix A of exogenous variable coefficients as:

$$
\begin{aligned}
& y^{\prime}=(B-I)^{\prime}+X^{\prime} A=\varsigma \\
& y^{\prime}=-X^{\prime} A(B-I)^{t-1}+\varsigma^{\prime}(B-I)^{t-1} \\
& y^{\prime} \equiv X^{\prime} \Pi+v \\
& \Pi \equiv-A^{\prime}(B-I)^{t-1}
\end{aligned}
$$

$\Pi_{h}$ And $\Pi_{h}^{\prime}$ the generic elements of the matrix

$v^{\prime} \equiv \varsigma(B-I)^{t-1}$

The variance-covariance matrix of error terms $E\left[v v^{\prime}\right]$ is

$E\left[v v^{\prime}\right]=(B-I)^{-1} \sum \Omega I(B-I)^{t-1}$

Then, the reduced form of the explicit system is the following:

$F C F_{i t}=\Pi_{0}^{\prime}+\Pi_{1}^{\prime}$ Leverage $_{i t}+\Pi_{2}^{\prime}$ Conc $_{i t}+\Pi_{3}^{\prime}$ Man $_{i t}+\Pi_{4}^{\prime}$ Inst $_{i t}+\Pi_{5}^{\prime}$ State $+\Pi_{6}^{\prime}$ Size $_{i t}+v_{1}^{\prime}$ Leverage $_{i t}=\Pi_{0}^{\prime}+\Pi_{1}^{\prime} F C F_{i, t 1}+\Pi_{2}^{\prime}$ Size $_{0}+\Pi_{3}^{\prime}{ }_{3}$ Tang $_{i t}+\Pi_{4}{ }_{4}$ Tax $_{i t}+\Pi_{5}^{\prime}$ Growth $_{i t}+\Pi_{6}{ }_{6}$ Profit ${ }_{i t}$ $+\Pi_{7}^{\prime}$ Risk $_{i t}+\Pi_{8}^{\prime}$ Ind $+v_{2}^{\prime}$ 


$$
\begin{aligned}
& \text { Payout }_{i, t}=\Pi_{0}^{\prime}+\Pi_{1}^{\prime} F_{C F_{i, t}}+\Pi_{2}^{\prime} \text { Leverage }_{i, t} \\
& +\Pi_{3}^{\prime} \text { Conc }_{i, t}+\Pi_{4}^{\prime} \text { Man }_{i, t}+\Pi_{5}^{\prime} \text { Inst }_{i, t}+\Pi_{6}^{\prime} \text { State }_{i, t} \\
& +\Pi_{7}^{\prime} \text { Size }_{i, t}+\Pi_{8}^{\prime} \text { Tang }_{i, t}+\Pi_{9}^{\prime} \text { Growth }_{, t}+\Pi_{10}^{\prime} \text { Profit }_{i, t} \\
& +\Pi_{11}^{\prime} \text { Risk }_{i, t}+v_{3}^{\prime}
\end{aligned}
$$

To this level the evaluation is done while applying the ordinary least square method, and we get $\hat{\Pi}$ the estimator of $\Pi$

$\hat{\Pi}=\left(X^{\prime} X\right)^{-1} X^{\prime} y$

This method permits us to get values $\hat{y}_{1}, \hat{y}_{2}$ and $\hat{y}_{3}$ serving to get the instrumental variables in the three equations. The following procedure consists in estimating every equation of the structural system while using the gotten instruments while applying the two least square methods (2SLS). So, we get an estimator $\hat{\sigma}_{s}$.

The objective will be to construct the estimated matrix of variance covariance matrix of error terms that is going to be used like ponderation matrix whose generic element $\hat{\sigma}_{i j}$ is:

$$
\hat{\sigma}_{i j}=\frac{\left(y_{i}-Z_{i} \hat{\delta}_{i}\right) \cdot\left(y_{j}-Z_{j} \hat{\delta}_{j}\right)}{n}
$$

$\mathrm{N}$ : the number of years.

The third and last stage consists in estimating simultaneously the three equations with the triple least square method (3SLS).

\section{Empirical results and discussion, three stage least square results}

Results of the joint estimation of free cash flow level, debt policy and dividend payout are presented at panel A, panel B and panel C of Table 4

Panel A: Equation ${ }_{1}: F C F_{i, t}=\alpha_{0}+\alpha_{1}$ Leverage $_{i, t}+\alpha_{2}$ Payout $_{i, t}+\alpha_{3}$ Conc $_{i, t}+\alpha_{4}$ Man $_{, t}+\alpha_{5}$ Inst $_{i, t}+\alpha_{6}$ State $_{i, t}+\alpha_{7}$ Size $_{i, t}+\varepsilon_{1 i, t}$

Table 4: Estimated coefficients for the leverage, free cash flow and dividend policy using Thtree-Stage Least Squares Method (3SLS)

\begin{tabular}{llll}
\hline Variable & Coefficient & t-Statistic & Prob. \\
\hline Constante & $-0,450$ & $-2,14$ & 0,032 \\
leverage & $-0,211$ & $-3,38$ & 0,001 \\
Payout & 0,053 & 1,54 & 0,124 \\
Conc & 0,385 & 2,44 & 0,015 \\
Man & $-0,568$ & $-9,92$ & 0,000 \\
Inst & $-0,199$ & $-2,84$ & 0,005 \\
State & $-0,331$ & $-4,67$ & 0,000 \\
Size & 0,035 & 0,74 & 0,457 \\
$\mathrm{R}^{2}$ & $29,39 \%$ & & \\
Number of observations & 206 & & \\
\hline
\end{tabular}

Equation $_{2}$ : Leverage $_{i, t}=\beta_{0}+\beta_{1} F C F_{i, t}+\beta_{2}$ Payout $_{i, t}+\beta_{3}$ Man $_{i, t}+$ $\beta_{4}$ Conc $_{i, t}+\beta_{5}$ Inst $_{i, t}+\beta_{6}$ State $_{i, t}+\beta_{7}$ Size $_{t}+\beta_{8}$ Tang $_{i, t}+\beta_{9}$ tax $_{t}$ $+\beta_{10}$ Rent $_{i, t}+\beta_{11}$ Risk $_{i, t}+\beta_{12}$ growth $_{i, t}+\beta_{13}$ Ind $_{i, t}+\varepsilon_{2 i}$

\begin{tabular}{llll}
\hline Variable & Coefficient & t-statistic & Prob, \\
\hline Constante & $-0,202$ & $-0,81$ & 0,416 \\
FCF & $-0,131$ & $-1,46$ & 0,144 \\
payout & $-0,022$ & $-0,46$ & 0,648 \\
Man & 0,405 & 2,53 & 0,011 \\
Conc & 0,233 & 1,43 & 0,152 \\
Inst & $-0,509$ & $-3,53$ & 0,000 \\
State & 0,312 & 5,14 & 0,000 \\
Size & 0,019 & 0,94 & 0,347 \\
Tang & $-0,244$ & $-2,54$ & 0,011 \\
Tax & $-0,070$ & $-0,31$ & 0,759 \\
Rent & $-1,097$ & $-4,36$ & 0,000 \\
Risk & $-0,014$ & $-0,10$ & 0,920 \\
Growth & $-0,083$ & $-1,01$ & 0,314 \\
Ind & 0,002 & 0,07 & 0,945 \\
R & $45,09 \%$ & & \\
Number of observations & 206 & & \\
\hline
\end{tabular}

Equation $_{3}:$ Div $_{i, t}=\delta_{0}+\delta_{1} F C F_{i, t}+\delta_{2}$ Dette $_{i, t}+\delta_{3}$ Conc $_{i, t}+\delta_{4}$ Dir $_{i, t}$ $+\delta_{5}$ Inst $_{i, t}+\delta_{6}$ Etat $_{\mathrm{i}, \mathrm{t}}+\delta_{7}$ Taille $_{i, t}+\delta_{8} Q_{\text {Tobin }}+\delta_{9}$ Tang $_{i, t}+$ $\delta_{10}$ Croiss $_{, t}+\delta_{11}$ Rent $_{i, t}+\delta_{12}$ Risk $_{i, t}+\varepsilon_{3 i}$

\begin{tabular}{llll}
\hline Variable & Coefficient & t-statistic & Prob, \\
\hline Constante & 1,479 & 4,50 & 0,000 \\
FCF & 0,066 & 0,48 & 0,633 \\
Leverage & $-0,453$ & $-4,82$ & 0,000 \\
Conc & $-0,455$ & $-1,90$ & 0,058 \\
Man & $-0,611$ & $-3,36$ & 0,001 \\
Inst & $-0,090$ & $-0,85$ & 0,396 \\
State & $-0,066$ & $-0,60$ & 0,545 \\
Size & $-0,060$ & $-2,14$ & 0,032 \\
Tang & $-0,236$ & $-1,71$ & 0,087 \\
ROA & 1,260 & 3,18 & 0,001 \\
Risk & 0,050 & 0,24 & 0,812 \\
Growth & 0,172 & 1,42 & 0,156 \\
$\mathrm{R}^{2}$ & $39,45 \%$ & & \\
nombre d'observations & 206 & & \\
\hline
\end{tabular}

The main results of the estimation can be interpreted as follows:

\subsection{Interaction between dividend policy and free cash flow}

A first observation is that the use of dividend policy does not significantly affect the level of free cash flow. Similarly, contrary to our expectations the coefficient associated with the variable risk free cash flow is positive but not significant in the equation of the dividend policy. Our hypothesis H1 is rejected. Our results, which are opposed to the free cash flow hypothesis of Jensen (1986) and contradict those of Smith and Watts (1992), Lang et al. (1996) and Gugler (2003) and Pappadopoulos and Dimitrios (2007), can be concluded that the mass distribution of dividends does not limit the discretionary management of excess cash and can no longer reduce the risk of free cash flow. In this case, the dividend policy cannot be considered in the context of listed Tunisian firms as a control mechanism used by the shareholders.

\subsection{The impact of debt policy on free cash flow levels}

The findings suggest that there is a significant impact of leverage which serves as a monitoring device to mitigate agency problem between owner and principal. The leverage variable has the negative predicted sign in the free cash flow equation and is statistically significant at the 0.01 level. Our hypothesis concerning the relation between the leverage and the free cash flow is therefore confirmed which corroborates the hypothesis of free cash flow of Jensen (1986) and confirms the empirical study of Wu (2004) who explore the implications of the free cash flow hypothesis concerning the disciplinary role of ownership structure in corporate capital structure policy. The author finds that the sensitivity of ownership structure to leverage depends on growth opportunities and free cash flow. When firms in the sample are classified as low-growth and high-growth firms, relation between leverage and free cash flow are significantly greater for low-growth firms than for the high-growth firms. Moreover, we observe evidence that firms with more severe overinvestment problem have higher levels of leverage and the coefficient of free cash flow are significantly positive, consistent with the free cash flow hypothesis. Also, our result corroborates the previous result of D'Mello and Miranda (2010) who shows that issuing debt leads to a dramatic reduction in this form of overinvestment and within three years of the offering the sample firms' cash ratios are similar to their industry benchmarks. Also, these relations are stronger for firms that have poor investment opportunities relative to other sample firms implying that debt plays an especially important role in reducing excess investments in firms that have the highest agency problems.

However, our result contradicts the empirical evidence of Nekhili et al., (2009) who show that it is distribution of dividends - rather than debt level - that leads to reduction of free cash flow. In sum, 
our results indicate that debt plays a critical role in reducing the agency costs of free cash flow in Tunisian firms.

\subsection{The impact of ownership structure on free cash flow levels}

Our results show that the coefficient associated to the ownership concentration has a positive and significant sign at the 0.01 level what demonstrate that firms characterized by the presence of a large blockholder have higher risk of free cash flow. Our result confirms the result of Nekhili et al., (2009) for the case of the French firms. Authors explain these findings by 3 arguments. First, the majority shareholders undertake nonprofit investments with other firms that are affiliated to them. Secondly, the majority shareholders cannot acquire all information detained by managers Third, the limited relationship that shareholders maintain with the entrenched managers doesn't permit them to criticize their choices However, results show that the coefficient of the variable "Man" is negative and statistically significant at the 0.01 level, in accordance with Jensen and Meckling's convergence of interest' hypothesis which suggest that managerial ownership serves to align the interests of mangers and outside shareholders. So, when managerial ownership increase, the risk to waste the free cash flow is limited and managers take fewer decisions that will have some negative effects on the firm value because the part of costs that they will absorb, as shareholders, increases with their part of the capital.

Our result corroborates Nekhili et al., (2009) and McKnight and Weir (2009) who suggest that increasing internal ownership helps to reduce agency costs.

Otherwise, analysis showed that institutional ownership had a non-significant effect on free cash flow. The non significant impact can be explained by the restricted part detained by the institutional investors in the capital of the Tunisian listed firms. Our findings corroborate the neutrality thesis of ownership structure developed by Demsetz (1983), Demsetz and Lehn (1985), and Demsetz and Villalonga (2001).

The coefficient of variable "State" is significant. We find a negative correlation between level of free cash flow and the state ownership at the 0.01 level which is in concordance with our hypothesis. As state ownership increases, there is more pressure on management to limit the wasting of free cash flow. Our results bring accusation a quasi - evident conclusion admitted by economists which is the primacy of the private sector. Also, they put in exergue the importance of public firms. In fact, these firms not only fill several social objectives but control also the behavior of managers. These results are essentially owed to the context of the study: a developing country where the state plays a determining role in the economic life and where the private sector cannot assure alone the good functioning of the economy.

In reality, the presence of the state stays until our days predominate in the most Tunisian firms in spite of the privatization program started since several years. The public powers constitute the authority of regimentation and thus define a set of measures to repressive character or purifying in order to discipline managers. Finally, larger firms, however, are also found to better use free cash flow at their disposal, which is inconsistent with the idea that larger firms generate greater agency costs. Alternatively, given the definition used to calculate free cash flows, it could be that larger firms are relatively less profitable which leaves lower cash flows available following debt financing and income distributions. Our finding confirms the result of Henry (2010).

\subsection{Impact of ownership structure on dividend policy}

The results show that the coefficient on the ownership concentration is negative and statistically significant at $10 \%$. Our results corroborate those of Nielsen (2006), Jiraporn and Ning (2006), Officer (2011) and Pan (2009), and that of Guizani and Kouki (2012) who find that listed Tunisian firms whose ownership is highly concentrated, limit the distribution of dividends. Our em- pirical results show, therefore, that the higher the percentage of shares held by the controlling shareholders, the lower the level of dividend payment. Our hypothesis $\mathrm{H} 2$ is rejected. This can be explained by the fact that the control imposed by large shareholders replaces the policy dividend as a governance mechanism. Indeed, a concentrated procreating stronger relationship between managers and shareholders ownership weakens the asymmetry of information and the need to report the situation of the firm through frequent changes of regular dividends. However, in our case, neither the concentration of ownership nor dividend policy serves as a mechanism for resolving agency conflicts of free cash flow. So we can say, like Harada and Nguyen (2011), our result contradicts the argument that the dividend policy replaces inspection by shareholders and supports rather the idea that controlling shareholders expropriate private benefits at the expense of minority shareholders. In fact, this negative relationship shows indeed that decisions within the firm will often be in the interests of the majority shareholders. The dividend decision as it affects their wealth is of paramount importance. Their preferences have no reason to be confused with those of minority shareholders. The risk aversion of the majority shareholders and their intention to expropriate minority shareholders through the extraction of private benefits are the cause of a low dividend.

In addition, our empirical results show that the coefficient on the managerial ownership is negative and significant, confirming our hypothesis $\mathrm{H} 3$ on the impact of managerial ownership on the level of dividend distribution. Our result is consistent with that of Poulain- Rehm (2005) and Boolaky (2009) and could be explained by the fact that in the case of Tunisian firms that are in most family-oriented, managers are usually major shareholders. It is legitimate to assume that they are less likely to carry unprofitable investments and destroy the value of the firm. In fact, we can say that from the reconciliation of the interests of managers and those of shareholders, result a lower payment that this combination may alleviate problems of free cash flow. Therefore, the need for high dividends or have a high level of debt is reduced. So for these firms dividends are only residual.

Finally, on the variable on the institutional ownership, it has a negative sign in the equation of free cash flow, negative and also significant in the equation of the debt, but negative and insignificant in the equation of dividends thus rejecting our hypothesis. Our results show that the institutional ownership allows more efficient use of excess cash and better control the level of free cash flow. The negative and significant effect of this variable on the level of free cash flow shows the willingness of institutional action , according to our hypothesis 1 rather directly on the level of excess cash (equation 1 ) and indirectly supported by a distribution dividends ( equation 3). Their presence substitute use of debt which in our case also acts negatively on the level of free cash flow.

\subsection{Interaction between debt policy and dividend policy}

We have seen through the review of the theoretical and empirical literature dealing with the relationship between dividend policy and debt policy that, in the agency context, debt and dividends are considered as two solutions of conflicts of interest. However, our empirical results (equation 1) show firstly that the variable "leverage" has a negative impact on the level of free cash flow, and secondly, an insignificant impact of dividends on the free cash flow. In addition, the empirical results related to the interaction between debt policy and dividend policy (Equation 2 and 3) show that debt is negatively affecting the rate of dividend distribution. However, the dividend policy seems not to have an effect on the level of debt when its coefficient is not significant in the equation of the debt. So our hypothesis H5 is verified. Nevertheless, our hypothesis $\mathrm{H6}$ is rejected.

Overall, our empirical results corroborate several studies have shown that the dividend policy and debt policy are two substitutable mechanisms in reducing the risk of free cash flow. Indeed, as shown in Jensen (1986), it is clear that the payment of dividends 
reduces the funds available to the managers. However, even if the manager is committed to the shareholders regularly increase dividends in the future, there is no guarantee it will be well. However, the increase in debt entitles bondholders to affirm the bankruptcy of the company in the case of non-repayment of debt. In other words, the debt in the future creates a forced restraint on liquidity of the firm minimizes the funds available to the manager while requiring him to perform better. In the case of our sample, managers must settle their debts to creditors. They must, therefore, assign the free cash flow to profitable projects. Thus, minimal debt agency costs of free cash flow and has, therefore, as a control mechanism which substitute's dividend policy.

In addition, in the case of Tunisian firms in our sample debt negatively affect the level of dividends due to agency conflicts that may exist between shareholders and creditors, especially bondholders. Indeed, the bondholders may impose restrictions on the distribution of dividends to ensure repayment of their debts especially as the debt ratio for Tunisian firms is high, which implies a low level of dividend payments in order to minimize the insolvency risk to the bondholders (Kalay, 1982 and Smith and Warner, 1979). Empirically, many studies confirm the negative impact of debt on the payment of dividends (Fama and French, 2001; Benito and Young, 2003; Yurtoglu and Gugler, 2003; Gwilym, Seaton and Thomas, 2004; Aivazian et al, 2006; Brockman and Unlu, 2009, Aggarwal and Kyaw, 2011). Our results confirm the importance of the pressure exerted by the creditors of the firm. This negative impact justifies, therefore, the importance of agency costs of debt, ie conflicts of interest that arise between shareholders, managers and creditors are a key factor in the dividend policy of firms.

On the impact of dividend policy on debt policy, it is no significant which contradicts the results of Bebczuk (2004), which states that firms with more access to debt distribute more dividends. Our result is opposed to the idea that states that firms with a high level of dividend should take on more debt and opposes, too, the pecking order theory that the dividend is funded by the use of debt in the event of insufficient funds.

\subsection{The dividend policy determinants}

On the other determinants of dividend policy, empirical results show a negative effect of tangible assets on the payout ratio. Our result contradicts that of Mullah (2000), confirming the words of Titman and Wessels (1988) and Alli et al. (1993) indicates that firms with more tangible assets pay more dividends.

For the variable on the size of the firm, it has a negative and statistically significant sign on the payout ratio indicating that large firms pay lower dividends. Our results contradict the majority of previous studies, on the determinants of dividend policy, but, confirm some studies that show a significant negative relationship between firm size and the level of dividend payment (Yurtuglu Gugler, 2003 and Farinha, 2003). The same result was shown by Kouki and Guizani (2012) in the context of listed Tunisian firms indicate that as the size of the firm increases, the need for a high dividend distribution is reduced. Indeed, firms that emit more information are large. Since the signal is costly, large firms reduce their level of dividend.

In addition, the results are in line with the signaling theory that the most profitable firms pay more dividends. Indeed, the managers of profitable firms must submit to current and potential investors a signal about the financial health of the company (Bhattacharya, 1979; Chang and Rhee, 2001; Ho, 2003; Aivazian et al., 2003).

\subsection{The Capital structure determinants}

In accordance with our anticipations the coefficient associated to the variable free cash flow is positive and statistically significant to the level of $5 \%$ in the equation of the debt. Our results show that firms with more severe overinvestment problem have higher levels of leverage. Jensen (1986) suggests that in case of low growth opportunities agency costs of free cash flow rise, so, debt should be issued. Indeed, probability of overinvestment by managers is reduced as firms commit to use future free cash flows for paying out investors.

Our findings show that the coefficient associated to the weight of immobilizations in the total of asset has a negative and significant sign at the 0.05 level. Our finding corroborates the empirical study of Hosono (2003) concerning the capital structure determinants of Manufacturing Firms in Japan.

Otherwise, this finding seems to confirm the pecking order theory that suggests that firms with few tangible assets will be most sensitive to the information asymmetry. So, they will use the debt that is an external financing vehicle less sensitive to information asymmetry that stocks (Harris and Raviv 1991). Indeed, in Tunisia the major part of the firm debt banking. According to Rajan and Zingales (1995), the tangibility of assets must take less importance in countries bank-dominated. Another explanation more specific to the Tunisian firms, and relative to the real value of fixed assets which is appreciated (and the appreciation has not been reflected in accounts of the firms), will be able to be to the origin of this relation.

Besides, profitability is strongly negatively related with leverage. This negative correlation demonstrates that the highly profitable firms have need of less external funds. It support for the pecking order theory by Myers and Majluf (1984). It is also consistent with Huang and Song (2006) for listed firms in China and Sheikh and Wang (2010) for firms listed on the stock market of Karachi. An explanation consists in considering that the profitable Tunisian firms are more incited to finance their activities by the financial markets and no by the debt. This finding also comes in support of the hypothesis that stipulates that managers choose the internal financing resource in the first place in order to control agency costs resulting from external financing.

Finally, it is to signal that no conclusion can be made as for the effect of the size, of the variation of the risk, of the firm growth and of the tax on the leverage from the moment the relative coefficients are not significant. In the same way, the relative coefficient to the variable «industry» is always non significant. In other words, the industrial firms don't appear nor more leveraged nor less leveraged than the non industrial firms. This finding comes in support of those found by Drobetz and Fix (2005) for the Swiss firms and Kim and al., (2006) for the non financial listed firms in Korea.

\section{Conclusion and implication}

The purpose of this paper is to explore the implications of the free cash flow hypothesis concerning the disciplinary role of ownership structure, capital structure and dividend policy in an emerging stock exchange such as that of Tunisia. We adopted the three stage least square simultaneous model approach basis of a sample composed of 35 non financial listed firms during the period going from 2000 to 2009 . Our results show that firms with more severe overinvestment problem have higher levels of leverage and the impact of the leverage on the free cash flow is significantly negative, consistent with the free cash flow hypothesis. Moreover, managerial ownership and state ownership has a negative effect on the level of free cash flow. Hence, in the Tunisian firms, the overinvestment problem can be mitigated by issuing debt and by increasing managerial and state ownership. However, the ownership concentration increases the risk of the free cash flow.

Our empirical results do not confirm our hypothesis implies that the solution to reduce the level of free cash flow in the Tunisian firms with low growth opportunities is the use of policy dividends. Regarding the impact of ownership structure on the payout ratio, our results support the idea that more risk aversion of the majority shareholders and their intention to expropriate minority shareholders through the extraction private benefits are the cause of a low dividend. In addition, the dividend policy is negatively affected by the managerial ownership and institutional investors favor the use 
of debt, which in our case is in turn negatively on the level of free cash flow.

In addition, the empirical results related to the interaction between debt policy and dividend policy show that the dividend policy and debt policy are two substitutable mechanisms in reducing the risk of free cash flow. It therefore appears that in the case of our sample, managers must settle their debts to creditors. They should thus allocate free cash flow to profitable projects. Thus, the debts are reduced agency costs of free cash flow and present as a control mechanism which substitute dividend policy.

\section{References}

[1] Agrawal A. and Knoeber C.R. 1996. Firm Performance and Mechanisms to Control Agency Problems between Managers and Shareholders. Journal of Financial and Quantitative Analysis 31 (3). 377-397.

[2] Aggarwal, R., N.A. Kyaw and X. Zhao, 2011, "Financial Environment and the ValueLeverage Relation." Journal of International Business and Economy (2011) 12(2): 1-26.

[3] Al-Deehani. T.M and Al-Saad.K.M 2007. Ownership Structure and Its Relationship with Capital Structure: An Empirical Study on the firms Listed in the Kuwait Stock Exchange. Arab Journal of Administrative Sciences Arab Journal of Administrative Sciences 14 (2)

[4] Al-khouri. R. 2006. Corporate governance and firm's value in emerging markets: the case of Jordan. Advances in Financial Economics 11 31-50.

[5] Andrés P., López F.J., and Rodríguez J.A. 2005. Financial Decisions and Growth Opportunities: A Spanish Firms Panel Data Analysis. Applied Financial Economics 15(6), 391- 407.

[6] Aoun. D and Heshmati. A. 2006. The Causal Relationship between Capital Structure and Cost of Capital: Evidence from ICT Companies Listed at NASDAQ . The Ratio Institute Working Papers 87.

[7] Bennett. M. and Donnelly. R. 1993. The Determinants of Capital Structure: Some UK Evidence. British Accounting Review. 25 1, 43 59.

[8] Berger P. Ofek E. and Yermach D. 1997. Managerial Entrenchment and Capital Structure Decisions. Journal of Finance 52. (4), 14111438.

[9] Billett. M.T. et al. 2007. Growth Opportunities and the Choice of Leverage, Debt Maturity, and Covenants. The Journal of Finance LXII (2), 697-730.

[10]Booth. L. Aivazian. V. Demirguc-Kunt. A. and Maksimovic. V. 2001 Capital structure in developing countries. Journal of Finance 56, 87130

[11]Brickley J. Lease R. and Smith C. 1988; Ownership structure and voting on a takeover amendments. Journal of financial economics 20 , 267-291.

[12]Buettner. Overesch. Schreiber. Wamser and George. 2009. Taxation and capital structure choice: Evidence from a panel of German multinationals. Economics Letters. 105 (3), 309-311

[13] Cadoret. B. Martin. H and Tanguy. 2004. Économétrie appliquée: méthodes, applications. corrigés. De Boeck Université.452 pages

[14]Cai K. R. Fairchild. And Guney. Y. 2008. Debt maturity structure of Chinese companies. Pacific-Basin Finance Journal 16, 268-297

[15]Chang. C. Lee. Alice C.and Lee. Cheng F. 2009. Determinants of capital structure choice: A structural equation modeling approach. The Quarterly Review of Economics and Finance 49, 197-213.

[16]Chen. J. J. 2004. Determinants of capital structure of Chinese-listed companies. Journal of Business Research 57, 1341 - 1351.

[17]Chen. X. and Yur-Austin. J. 2007. Re-measuring agency costs: The effectiveness of blockholders. The Quarterly Review of Economics and Finance 47(5), 588-601.

[18]Ciceksever. B. J. Kale. And H. Ryan. 2006. Corporate governance, debt, and activist institutions. Georgia State University working paper.

[19]De Jong A. and Dijk R.V. 2007. Determinants of Leverage and Agency Problems: A Regression Approach with Survey Data. European Journal of Finance 13(6), 565-593.

[20]De Jong.A. Kabir.T.T and Nguyen. R. 2008. Capital structure around the world: The roles of firm- and country-specific determinants. Journal of Banking and Finance 32( 9), 1954-1969

[21]De Miguel. A. and Pindado J. 2001. Determinants of capital structure: new evidence from Spanish panel data. Journal of Corporate Finance 7, 77-99

[22]Del Brio E. Perote J. and Pindado J. 2003. Measuring the Impact of Corporate Investment Announcements on Share Prices: the Spanish Experience. Journal of Business. Finance and Accounting 30,715-747.
[23]Delcoure N. 2007. The determinants of capital structure in transitional economies. International Review of Economics and Finance. 16, 400415.

[24]Demsetz.H. 1983. The structure of ownership and the theory of the firm. Journal of Law and Economics 2 (June), 375-390.

[25]Demsetz.H. and Lehn K. 1985. The structure of corporate ownership: causes and consequences. Journal of Political Economy 93(6), 11551177.

[26]Demsetz.H. and Vilallonga B. 2001. Ownership structure and corporate performance. Journal of Corporate Finance 7(3), 209-233.

[27]D'Mello.R. and Miranda.M. 2010. Long-term debt and overinvestment agency problem. Journal of Banking and Finance 34, 324-335

[28]Doukas. J.A. C. Kim. And C. Pantzalis. 2005. Security Analysis, Agency Costs and Firm Characteristics. International Review of Financial Analysis 14(5), 493-507

[29]Driffield.N.L. and Pal .S. 2007. How does ownership structure affect capital structure and firm performance? Recent evidence from East Asia. Economics of Transition 15 (3), 535-573

[30]Drobetz W and Fix R. 2005. What are the determinants of the capital structure? Some evidence for Switzerland. Revue Suisse d'Economie et de statistique 1(mars), 71-114.

[31]Duggal R. and Millar J.A.1999. Institutional ownership and firm performance: The case of bidder returns. Journal of Corporate Finance 5 .

[32]Ezeoha. A.E. 2008. Firm size and corporate financial leverage choice in a developing economy. The Journal of Risk Finance. 94. 351-364.

[33]Faccio M. and Lasfer M.A. 2002. Institutional Shareholders and Corporate Governance: The Case of U.K. Pension Funds In: J. McCahery. P. Moerland. T. Raaijmakers. And L. Renneboog. Eds. Corporate Governance Regimes: Convergence and Diversity. Oxford University Press.

[34]Fattouh. Scaramozzino and Harris 2005. Capital structure in South Korea: a quantile regression approach. Journal of Development Economics 761, 231-250.

[35]Flannery. M.J. and K.P. Rangan. 2006. Partial adjustment toward target capital structures. Journal of Financial Economics79(3) 469506

[36]Fluck. Z. D. Holtz-Eakin. And H.S. Rosen. 2000. Where does the money come from? The financing of small entrepreneurial enterprises, New York University Working paper.

[37]Frank. M. andGoyal. V. 2000. Testing the pecking order theory of capital structure. Journal of Financial Economics 67( 2), 217-248

[38] Garvey G.T. and G. Hanka. 1999. Capital structure and corporate control: the effect of anti-takeover statutes on firm leverage. Journal of finance 54 (2), 519-546

[39] Ghosh. S. 2007. Leverage, managerial monitoring and firm valuation: A simultaneous equation approach. Research in Business 61, 84-98.

[40]Graham. J.R. and Tucker. A.L. 2006. Tax shelters and corporate debt policy. Journal of Financial Economics 81, 563-594.

[41] Grossman. S. J. And O. D. Hart 1982. Corporate Financial Structure and Managerial Incentives. In: The Economics of Information and Uncertainty. Ed. Par J. J. McCall. Chicago: The University of Chicago Press, 123-155

[42]Guizani and Kouki (2012), "Ownership-Control Discrepancy and Dividend Policy: Evidence from Tunisia", International Business Research, Vol 5, No 1.

[43]Gul F.A. Jaggi B. 1999. An analysis of joint effects of investment opportunity set. Free cash flow and size on corporate debt policy. Review of Quantitative Finance and Accounting 12(4), 371-381.

[44]Halov N and Heider.F. 2005. Capital Structure, asymmetric information and risk. EFA 2004 MAASTRICHT, 1-56.

[45] Harada \& Nguyen, 2011. "Ownership concentration and dividend policy in Japan," Managerial Finance, Emerald Group Publishing, vol. 37(4)

[46]Harris M. and Raviv.A. 1991. The theory of capital structure. Journal of Finance 46(1), 297-355

[47]Henry. 2010. Agency costs, ownership structure and corporate governance compliance: A private contracting perspective. Pacific-Basin Finance Journal 181, 24-46.

[48] Hosono 2003. Growth Opportunities. Collateral and Debt Structure: The Case of the Japanese Machine Manufacturing Firms. Japan and the World Economy 15(3), 275-97.

[49]Hovakimian 2006. Are Observed Capital Structures Determined by Equity Market Timing? Journal of Financial and Quantitative Analysis 41 (1), 221-243

[50]Huang. G. and F.M. Song. 2006. The Determinants of Capital Structure: Evidence from China. China Economic Review 17, 14-36

[51]Hudson M.R. Parrino R. and Starks L. 1998. International monitoring mechanisms and CEO turnover: A long term perspective. Unpublished manuscript University of Pennsylvania. 
[52]Imam. M and Malik. M 2007. Firm Performance and Corporate Governance through Ownership structure. International Review of Busi ness Research Papers 3(4), 88-110

[53]Jensen. M. and Meckling. W. 1976. Theory of the firm: Managerial behavior, agency costs and capital structure. Journal of Financial Economics 3, 305-360

[54]Jensen. M. 1986. Agency costs of free cash flow, corporate finance and takeovers. American Economic Review 76, 323-329

[55] Karadeniz. S. Y. Kandir. M. Balcilar and Y. B. Onal. 2009. Determinants of capital structure: evidence from Turkish lodging companies. International Journal of Contemporary Hospitality Management 215, 594-609

[56]Kim. H. Heshmati. A. and Aoun. D. 2006. Dynamics of capital structure: the case of Korean listed manufacturing companies. Asian Economic Journal 203, 275-302.

[57]Kouki M. \& Guizani M. (2009), "Ownership Structure and Dividend Policy Evidence from the Tunisian Stock Market", European Journal of Scientific Research, Vol.25, No.1, and pp: 42-53.

[58]Kremp E. and Stoss E. 2001. L'endettement des entreprises industrielles françaises ET allemandes: des élutions distinctes malgré des déterminants proches. Economie ET Statistique $\mathrm{n}^{\circ} 1 / 2$

[59]La Rocca. La Rocca and Cariol 2007. Overinvestment and Underinvestment Problems: Determining Factors: Consequences and Solutions. Corporate Ownership and Control 5 (1), 79-95

[60]Lambrecht B. M.and Myers S. C. (2010)"A Lintner model of dividends and managerial", NBER working paper 16210, forthcoming Journal of Finance.

[61]Lang L.H.P. Ofek O. and Stulz R.M. 1996. Leverage, Investment. And Firm Growth. Journal of Financial Economics 40, 3-29.

[62]McKnight and Weir. 2009. Agency costs, corporate governance mechanisms and ownership structure in large UK publicly quoted companies: A panel data analysis. The Quarterly Review of Economics and Finance 49, 139-158.

[63]Michaely, Roni and Michael R. Roberts, 2012, Corporate Dividend Policies: Lessons from Private Firms, Review of Financial Studies 25, 711-746.

[64]Miller. Merton H. 1977. Debt and Taxes. Journal of Finance, 261-275.

[65]Miller. Merton H. 1991. Leverage. Journal of Finance 46 (2), 479-488

[66]Modigliani F. and M. Miller 1958. The cost of capital, corporation finance and the theory of investment. American Economic Review, 261-297.

[67]Modigliani F. and M. Miller 1963. Corporate Income Taxes and the cost of capital. American Economic Review, 433-443.

[68] Myers. Stewart C. 1977. Determinants of Corporate Borrowing. Journal of Financial Economics 5(2), 147-175

[69]N. Eriotis. V. Dimitrios and V. N. Zoe. How firm characteristics affect capital structure: an empirical study. Managerial Finance 335, 321331.

[70]Nekhili M. Wali A. and Chebbi D. 2009. Free cash flow, gouvernance ET politique financière des entreprises françaises. Finance Contrôle Stratégie 12 (1), 5-31.

[71]Pao. 2008. A comparison of neural network and multiple regression analysis in modeling capital structure Expert Systems with Applications 35, 720-727

[72]Pindado J. and De la Torre C. 2005. A Complementary Aroach to the Financial and Strategy Views of Capital Structure: Theory and Evidence from the Ownership Structure. SSRN working paper.

[73]Poulain-Rehm T. 2005. L'impact de l'affectation du free cash flow sur la création de valeur actionnariale: le cas de la politique d'endettement et de dividendes des entreprises françaises cotées. $R e$ vue Finance. Contrôle. Stratégie 8 (4), 205-238.

[74]Pound J. 1988; Proxy contests and the efficiency of shareholder oversight. Journal of financial economics 20, 237-266.

[75]Rajan R.G. and Zingales. L. 1995. What do we know about capital structure? Some evidence from international data Journal of Finance 50(5), 1421-1460

[76]Sheikh and Wang 2010. Financing Behavior of Textile Firms in Pakistan. International Journal of Innovation. Management and Technology 1 (2), 130-135.

[77] Shyam-Sunder L. and S.C Myers 1999. Testing static tradeoff against pecking order models of capital structure. Journal of Financial Economics 51, 219-244.

[78]Singh M. and Davidson III W.N. 2003. Agency costs, ownership structure and corporate governance mechanism. Journal of Banking and Finance 27, 793-816.

[79]Solh. M. 2000. Fonds de pension ET politique d'investissement à long terme des entreprises. thèse de doctorat en sciences de gestion. Université de Paris X Nanterre

[80]Stulz. 1990. Managerial Discretion and Optimal Financing Policies. Journal of Financial Economics 26, 3-27
[81] Taggart. 1977. A model of corporate financing decisions. Journal of Finance 32, 1467-1484

[82] Tang. C.H. and Jang. S.C. 2007. Revisit to the determinants of capital structure: A comparison between lodging firms and software firms. International Journal of Hospitality Management 261, 175-187.

[83]Titman and Wessels 1988. The determinants of capital structure choice. Journal of Finance 43, 1-19.

[84] Vilasuso. J and Minkler. A. 2001. Agency costs, asset specificity, and the capital structure of the firm. Journal of Economic Behavior and Organization 441, 55-69.

[85] Wiwattanakantang and Yupana. 1999. An empirical study on the determinants of the capital structure of Thai firms . Pacific-Basin Finance Journal 73(4), 371-403.

[86] Wu and Yue 2009. Corporate tax, capital structure. and the accessibility of bank loans: Evidence from China. Journal of Banking and Finance 33(1), 30-38

[87] Wu L. 2004. The Impact of Ownership Structure on Debt Financing of Japanese Firms with the Agency Cost of Free cash flow. EFMA Meetings Paper.

[88]Zhang. H and Li. S. 2008. The Impact of Capital Structure on Agency Costs: Evidence from UK Public Companies. Proceedings of the 16th Annual Conference on Pacific Basin Finance Economics Accounting Management PBFEAM Conference.

[89]Zou.H. and J. Z. Xiao. 2006. The financing behavior of listed Chinese firms. The British Accounting Review 38, 239-258.

[90]Zwiebel J. 1996. Dynamic Capital Structure under Managerial Entrenchment. American Economic Review 86 (5), 1197-1215. 